\title{
O DIREITO INTERNACIONAL DO MEIO AMBIENTE E O GREENING DA CONVENÇÃO AMERICANA SOBRE DIREITOS HUMANOS
}

Valerio de Oliveira Mazzuoli e Gustavo de Faria Moreira Teixeira

\section{RESUMO}

ESTE ARTIGO TEM COMO OBJETIVO BUSCAR UMA BREVE REFLEXÃO SOBRE AS INTER-RELAÇÕES ENTRE A PROTEÇÃO INTERNACIONAL DO MEIO AMBIENTE E DOS DIREITOS HUMANOS E ANALISAR AS CONTRIBUIC̄õES DO CHAMADO GREENING OU "ESVERDEAMENTO" DO SISTEMA INTERAMERICANO DE DIREITOS HUMANOS - FENÔMENO QUE OCORRE QUANDO SE PROTEGE DIREITOS DE CUNHO AMBIENTAL POR MEIO DE DISPOSITIVOS DA CONVENÇÃO AMERICANA SOBRE DIREITO HUMANOS, QUE SÃO VOLTADOS EM PRINCÍPIO À GARANTIA DE DIREITOS CIVIS E POLÍTICOS.

\section{PALAVRAS-CHAVE}

Direitos humanos; MeIO ambiente; Sistema interamericano; Defesa pela via ReFleXa; Greening; Convenção Americana SOBRE DiREITOS HUMANOS.

\section{ABSTRACT}

THIS ARTICLE AIMS TO SEEK A BRIEF REFLECTION ON THE INTERRELATIONSHIPS BETWEEN THE INTERNATIONAL ENVIRONMENTAL PROTECTION AND THE HUMAN RIGHTS ISSUES AND TO ANALYZE THE CONTRIBUTIONS OF THE PROCESS OF GREENING THE INTER-AMERICAN HUMAN RIGHTS SYSTEM A PHENOMENON THAT OCCURS WHEN ENVIRONMENTAL ISSUES ARE PROTECTED BY THE AMERICAN CONVENTION ON HUMAN RIGHTS DEVICES, WHICH ARE IN PRINCIPLE FOCUSED ON THE GUARANTEE OF CIVIL AND POLITICAL RIGHTS.

\section{KEYWORDS}

HUMAN RIGHTS; ENVIRONMENT: INTER-AMERICAN SYSTEM;

THE REFLEX PATHWAY DEFENSE; GREENING; AMERICAN

CONVENTION ON HUMAN RIGHTS.

\section{INTRODUÇÃO}

Em que pese a Convenção Americana sobre Direitos Humanos de 1969 (também conhecida por Pacto de San José da Costa Rica) - assim como a Convenção Europeia de Direitos Humanos de 1950 - não possuir em seu texto qualquer direito de cunho ambiental, o certo é que a prática tanto da Comissão quanto da Corte Interamericana de Direitos Humanos tem demonstrado que no plano do sistema regional interamericano é possivel amparar (proteger, garantir etc.) temas ligados ao meio ambiente, cuja influência é exemplificada por um fenômeno chamado greening (ou "esverdeamento") do direito internacional. ${ }^{1}$ Para tanto, faz-se necessário desenvolver estratégias e técnicas capazes de vincular temas ambientais aos dispositivos da Convenção Americana, 
como os relacionados às garantias judiciais, à liberdade de expressão, ao direito de propriedade, entre outros.

Desvendar esse universo de possibilidades, atinentes à proteção do meio ambiente nos sistemas regionais de direitos humanos, em especial, no sistema interamericano, é o objeto principal deste ensaio.

\section{O DIREITO DAS FUTURAS GERAÇÕES E A INTER-RELAÇÃO ENTRE DIGNIDADE HUMANA E UM AMBIENTE SADIO}

A proteção dos chamados direitos das futuras gerações tem sua origem não na consciência ambiental, mas sim na década de 1940 e nos traumas de uma geração que testemunhou os horrores de duas grandes guerras e que, por temer a devastação de futuros conflitos globais, pressentia a urgente necessidade de implantar mecanismos de proteção efetiva dos direitos humanos. É dessa forma que do preâmbulo da Carta das Nações Unidas (1945) se observa: "Nós, os povos das nações unidas, resolvidos a preservar as gerações vindouras dos flagelos da guerra, que por duas vezes no espaço de nossas vidas trouxe sofrimentos indivisíveis à humanidade, e a reafirmar a fé nos direitos fundamentais do homem [...] resolvemos conjugar nossos esforços para consecução desses objetivos”.

O homem do pós-guerra, no entanto, não tardou a perceber que a dignidade humana estava não só ameaçada pela possibilidade de guerras apocalípticas, mas também pela deterioração que o próprio homem vinha impondo ao meio ambiente. Os perversos efeitos do vazamento das indústrias químicas, a poluição transfronteiriça em rios internacionais, os acidentes com os superpetroleiros, os riscos de catástrofes provenientes das usinas nucleares, a independência dos países africanos nos anos 1960 e a inserção de novos atores na geopolítica mundial complementaram o mosaico de fatores que aceleraram os debates e o nascimento do direito internacional ambiental em 1972, com a Declaração de Estocolmo sobre o Meio Ambiente Humano, e que, vinte anos mais tarde, contribuíram para com a maturidade da temática ambiental, na Conferência das Nações Unidas do Rio de Janeiro (conhecida como ECO 92). ${ }^{2}$

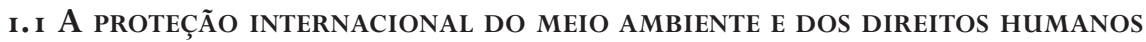

O direito do meio ambiente construído por Estocolmo e Rio de Janeiro é estruturado a) pela inserção do acesso a um ambiente sadio no rol dos direitos humanos de solidariedade e $b$ ) pela preocupação com o desenvolvimento sustentável, ou seja, com a "satisfação das necessidades das gerações presentes, sem comprometer a capacidade das gerações futuras em satisfazer as suas necessidades". ${ }^{3}$

Nesse sentido, a partir de Estocolmo (1972), deu-se um processo de construção de uma ordem internacional em que as políticas ambientais são orientadas por princípios 
tais como a responsabilidade comum, porém diferenciada, a utilização dos recursos compartilhados, justiça ambiental, os princípios do poluidor pagador, do desenvolvimento sustentável, da precaução e da prevenção (este último definido por Alexandre Kiss e Dinah Shelton como "a regra de ouro do meio ambiente"). ${ }^{4}$

\section{I. I A “ENGENHARIA” DA PROTEÇÃo INTERNACIONAL AO MEIO AMBIENTE}

Vinte anos após a Conferência Internacional sobre Meio Ambiente em Estocolmo 1972, o encontro de delegações de 175 países na cidade do Rio de Janeiro, entre 3 e 14 de junho de 1992, na Conferência das Nações Unidas sobre Meio Ambiente e Desenvolvimento, também conhecida como ECO 92, reafirmou os princípios de universalidade, indivisibilidade e interdependência dos direitos humanos vinculando-os à proteção ambiental e produziu a Convenção sobre Mudança do Clima, a Convenção sobre Biodiversidade, a Declaração de Princípios sobre Florestas, a adoção da Agenda 21 - um plano de ação voltado para adoção do desenvolvimento sustentável em todos os países - e a estruturação de uma "nova engenharia” (para falar como Guido Soares) na proteção internacional do meio ambiente. ${ }^{5}$

Tradicionalmente, a entrada em vigor dos tratados internacionais obedece a um complexo e longo trâmite ${ }^{6}$ que acompanha as negociações preliminares, a assinatura, ${ }^{7}$ a adoção, a aprovação ${ }^{8}$ e a ratificação ou adesão de um Estado aos termos de um tratado. A nova engenharia produzida no Rio de Janeiro gira em torno de uma notável aceleração dos mecanismos de adoção e entrada em vigor de normas internacionais relacionadas ao meio ambiente.

O direito internacional do meio ambiente moderno é estruturado por uma técnica de atualização que consiste na adoção de anexos, apêndices e termos genéricos nos tratados "mais emblemáticos" que propositadamente formam grandes tratados-quadro, ou seja, um vasto campo normativo a ser complementado por intermédio de decisões advindas de futuras reuniões periódicas dos Estados-partes, as chamadas Conferências das Partes ou COPs. ${ }^{9}$

As decisões das COPs têm se fundamentado em estudos técnicos e científicos de órgãos subsidiários, instituídos anteriormente pelos tratados-quadro. Tais órgãos, como destaca Guido Soares, "passam a ser, no campo de sua competência, os guardiões das normas já em vigor, ademais daquelas constantes nos tratados multilaterais”. ${ }^{10}$

A nova engenharia do direito internacional do meio ambiente imprime maior agilidade à dinâmica dos tratados ambientais ao permitir aos Estados que assumam compromissos iniciais baseados em um plano de ação comportamental, que se vai consolidando com a conclusão gradativa de protocolos adicionais sobre cada tema específico a ser tratado. ${ }^{11}$

No entanto, essa nova engenharia não é livre de desvantagens. A primeira delas diz respeito à dificuldade em torno do entendimento das normas internacionais de proteção ambiental, uma vez que, sem o constante acompanhamento das atualizações 
feitas pelas COPs, a leitura dos tratados-quadro por si só não é suficiente para trazer esta compreensão plena.

Outro desafio à nova engenharia reside no fato de esta ser estruturada por normas de soft law. Apesar de indicarem "obrigações morais" dos Estados, as normas de soft law não possuem status de norma jurídica e, por isso, não tem força vinculante. ${ }^{12}$ Assim, os Estados que vierem a descumprir suas "obrigações morais" relacionadas à proteção ao meio ambiente, não podem sofrer sanções da comunidade internacional.

Esse "compromisso moral” é ainda fragilizado por COPs com objetivos mal delineados, pela falta de poder e influência do Programa das Nações Unidas para o Meio Ambiente (PNUMA) nos foros diplomáticos e pela incapacidade ou falta de interesse dos Estados em criar uma organização intergovernamental especificamente voltada a questões ambientais. ${ }^{13}$

Ademais, a "nova engenharia" do direito ambiental não foi capaz de criar um sistema de proteção aos direitos de solidariedade uma vez que apenas os direitos civis, políticos, econômicos, sociais e culturais são objeto de sistemas de proteção da ONU e das organizações regionais. ${ }^{14}$

A necessidade de um sistema global de proteção aos direitos de solidariedade é evidenciada por Antônio Augusto Cançado Trindade, nestes termos: "Este é um ponto que certamente merece mais pesquisa e reflexão. [...] Já é tempo de voltarmos agora nossa atenção e reflexão à necessária concepção de alguma forma de institucionalização da implementação do direito ao desenvolvimento como um direito humano nos próximos anos". 15

O fortalecimento dos mecanismos institucionais de proteção aos direitos de solidariedade, reivindicado por Cançado Trindade, tem sido feito pela vinculação da causa ambiental aos direitos civis e políticos, econômicos, sociais e culturais; ou seja, é feito pelo "diálogo" entre as atuais normas de proteção ambiental e os sistemas internacionais de proteção aos direitos humanos. ${ }^{16}$

\section{I. 2 O Sistema global de PROTEÇÃo aOS DiReitos humanos}

O vigente sistema global de proteção aos direitos humanos passa a ser estruturado a partir de 1945, ano em que a cidade de São Francisco foi palco de uma "silenciosa e quase despercebida revolução" 17 provocada por uma Conferência que resultou na Carta das Nações Unidas, documento de fundação de uma organização internacional global (a maior de todas atualmente, em estrutura e importância) voltada a evitar que as horrorosas cenas da Segunda Guerra tornassem a ocorrer. ${ }^{18}$

A Carta das Nações Unidas ostenta, logo em seu primeiro artigo, a necessidade de "promover e estimular o respeito aos direitos humanos e às liberdades fundamentais”. No entanto, a Carta não definiu quais são esses “direitos humanos" e quais são as "liberdades fundamentais". Daí a necessidade da elaboração de outro instrumento, três anos depois, que viesse positivar tais direitos humanos e liberdades fundamentais 
mínimos: a Declaração Universal dos Direitos Humanos, proclamada em Paris, no dia 10 de dezembro de 1948.

A Declaração de 1948 protege duas espécies de direitos: os direitos civis e políticos (arts. $3^{\circ}$ a 21), e os direitos econômicos, sociais e culturais (arts. 22 a 28). São direitos civis aqueles ligados à concepção do Estado Liberal e à valorização do indivíduo frente aos excessos do Estado. Assim, o século XX dominado ainda pelos ideais liberais do século XVIII consolida a não intervenção estatal na liberdade pessoal, no pensamento e na religião dos indivíduos, ou seja, o dever do Estado em não agir ou não se intrometer na vida civil ou privada de seus cidadãos. ${ }^{19}$ Por sua vez, os direitos econômicos, sociais e culturais implicam uma ação dos Estados no "emprego do 'máximo de recursos possíveis' por parte de cada um" 20 em políticas favoráveis ao desenvolvimento, como as garantias aos direitos ao trabalho, à assistência médica, à educação, ao combate à pobreza etc. ${ }^{21}$

A Declaração Universal de 1948, no entanto, por si só, “apenas” interpretou a expressão "direitos humanos" presente na Carta da ONU, sem determinar como os Estados deverão garantir esses direitos e sem estabelecer qualquer monitoramento ou sanção internacional aos Estados que descumprirem seus fundamentos. Para tal, as Nações Unidas, em 1966, viabilizaram um sistema global de proteção aos direitos humanos "subdividido" em dois pactos internacionais: o Pacto Internacional dos Direitos Civis e Políticos e o Pacto Internacional de Direitos Econômicos, Sociais e Culturais. Ambos adotam a análise periódica de relatórios como instrumento de monitoramento da ação dos Estados na proteção aos direitos humanos. Em especial, o Pacto Internacional dos Direitos Civis e Políticos adota dois outros instrumentos de monitoramento internacional: as comunicações interestatais e o direito de petição individual aos organismos internacionais. ${ }^{22}$ Outro legado positivo dos Pactos de Nova York é o fato de estes não inviabilizarem, de forma alguma, a proteção de especificidades culturais que não tenham alcance global ou universal. Nesse sentido, o $\S 5^{\circ}$ da Declaração e Programa de Ação de Viena de 1993 esclarece que "particularidades nacionais e regionais devam ser levadas em consideração, assim como diversos contextos históricos, culturais e religiosos". 23

Tal lógica de "enriquecimento da universalidade dos direitos humanos pela diversidade cultural" 24 fortaleceu a legitimidade dos sistemas regionais de proteção a direitos humanos que, em complemento ao sistema global, tem como objetivo promover e proteger direitos e valores tidos como fundamentais de acordo com as particularidades culturais de determinada região.

São três os sistemas regionais de proteção, todos estruturados por meio de tratados internacionais, que limitam a soberania estatal: o europeu, fundamentado na Convenção Europeia para a Proteção de Direitos Humanos e das Liberdades Fundamentais de 1950, complementada por vários protocolos e pela Carta Social Europeia de 1961; o africano, fundamentado na Carta Africana de Direitos do Homem e dos Povos de 1981; e o 
interamericano, fundado em dois sistemas distintos, mas que se complementam um regido pela Carta da Organização dos Estados Americanos e pela Declaração Americana de Direitos e Deveres, e outro fundamentado na Convenção Americana de Direitos Humanos (o Pacto de San José da Costa Rica) de 1969. ${ }^{25}$

\section{I.2 A INSERÇÃo DA TEMÁtiCA AMBIENTAL NOS SISTEMAS INTERNACIONAIS DE PROTEÇÃo AOS DiREITOS HUMANOS}

A complexa rede criada para proteger direitos humanos definidos pela Declaração Universal de 1948 teve, a partir de 1972, de se adaptar à nova concepção de que o acesso a um ambiente sadio é também um direito humano a ser garantido. Com isso, a tradicional classificação das concepções de direitos humanos passa a sofrer severas críticas, uma vez que a percepção de uma primeira, segunda e terceira gerações de direitos, ou seja, respectivamente, os direitos civis e políticos (previstos nos arts. $3^{\circ}$ a 21 da Declaração Universal de 1948), os direitos econômicos, sociais e culturais (constantes dos arts. 22 a 28 da mesma Declaração) e os direitos de solidariedade (expressos nos 26 princípios da Declaração de Estocolmo), poderia realçar "uma conotação negativa de sucessão temporal e decadência”. ${ }^{26}$

A importantíssima Declaração de Direitos Humanos de Viena de 1993 vem sanar esse possível mal-entendido ao afirmar, em seu $\S 5^{\circ}$, que todos "os direitos humanos são universais, interdependentes e inter-relacionados", e que a "comunidade internacional deve tratar os direitos humanos globalmente de forma justa e equitativa, em pé de igualdade e com a mesma ênfase". ${ }^{27}$ Portanto, não restam dúvidas de que os direitos humanos, e suas Declarações de 1948 e de 1972, não rivalizam, pelo contrário, se complementam.

O Princípio 1 da Declaração de Estocolmo de 1972 reforça tal assertiva ao vincular o acesso a uma ambiente sadio à garantia de liberdade, qualidade de vida e dignidade, todos valores das chamadas primeira e segunda gerações:

O homem tem o direito fundamental à liberdade, igualdade e adequadas condições de vida, em um ambiente cuja qualidade permita uma vida de dignidade e bem estar, e tem solene responsabilidade de proteger e melhorar o meio ambiente, para a presente e as futuras gerações. A tal respeito, as políticas de promover e perpetuar o apartheid, a segregação racial, a discriminação, a opressão colonial e suas outras formas, e a dominação estrangeira, ficam condenadas e devem ser eliminadas.

A lógica de Estocolmo, portanto, evidencia que a questão da proteção ambiental não se limita ao controle da poluição ou do desmatamento. Pelo contrário: abrange um universo amplo e complexo, que envolve e interliga todas as concepções de direitos humanos. Reforça ainda tal argumento o fato de a Resolução n. 217 da Assembleia 
Geral da ONU ter reconhecido que os 26 princípios da Declaração de Estocolmo possuem a mesma relevância da Declaração Universal dos Direitos Humanos de 1948, servindo, portanto, de grandes referenciais éticos. ${ }^{28}$

A Declaração de Estocolmo também produziu efeitos de âmbito jurídico interno. Após 1972, séries de textos e reformas constitucionais supervenientes incluíram a proteção ao meio ambiente no rol de direitos humanos fundamentais de tal forma que atualmente mais de cem constituições asseguram o acesso ao meio ambiente "saudável”, "seguro", "limpo", ou "equilibrado". ${ }^{29}$ Esta "ecologização da ordem jurídica”30 das constituições pós-Estocolmo é marcada pelo fortalecimento do princípio da solidariedade das gerações, que implica a obrigatoriedade de as sociedades atuais aplicarem medidas que atendam aos interesses das futuras gerações, garantindo à humanidade o acesso a um ambiente sadio, a direitos civis, políticos, econômicos, sociais e culturais. ${ }^{31}$

\section{I.2. I O DIREITO DE ACESSO A UM MEIO AMBIENTE SADIO E OS INSTRUMENTOS INTERNACIONAIS DE PROTEÇÃO AOS DIREITOS HUMANOS}

A evolução dos mecanismos de proteção ao meio ambiente reforçou ainda mais as interconexões entre o acesso ao ambiente sadio e os direitos humanos. A Resolução n. 44/228, de 1989, da Assembleia Geral da ONU que convocou a Conferência das Nações Unidas sobre Meio Ambiente e Desenvolvimento em 1992, reconhece o caráter global dos problemas ambientais e vincula a melhoria do meio ambiente à proteção das condições da saúde humana e à melhoria da qualidade de vida. Os preâmbulos das convenções sobre Mudança Climática e sobre Diversidade Biológica de 1992 fazem referências expressas ao objetivo fundamental e urgente de erradicar a pobreza. Por sua vez, a Agenda 21, adotada na mesma Conferência reconhece que a degradação ao meio ambiente tem produzido grupos de vulneráveis como os pobres das áreas urbanas e rurais, os povos indígenas, as crianças, as mulheres, os idosos, os sem-teto, os doentes terminais e as pessoas portadoras de deficiência, que se veem privados de necessidades essenciais ao ser humano como: alimentação, preservação da saúde, moradia adequada e educação. ${ }^{32}$

Em 1993, a Conferência Mundial sobre Direitos Humanos em Viena - além do histórico reconhecimento da universalidade, interdependência e inter-relação dos direitos humanos por intermédio do $\S 5^{\circ}$ de sua Declaração - resultou na fixação em seu Programa de Ação de objetivos relacionados aos princípios da Declaração do Rio, a políticas de desenvolvimento sustentável da Agenda 21, bem como aos esforços globais em prol de direitos econômicos, sociais e culturais como saúde e bem-estar, alimentação, cuidados médicos, moradia e serviços sociais indispensáveis. ${ }^{33}$

Para Cançado Trindade, a vinculação entre meio ambiente e direitos humanos implicou $^{34}$ a transição da fase da internacionalização da proteção ambiental - marcada pela preocupação com a proteção ambiental em zonas sob a competência territorial 
dos Estados e suas implicações com a poluição transfronteiriça - para a fase da globalização, em que "os princípios de caráter global aplicam-se aos territórios dos Estados, independente de qualquer efeito transfronteiriço, e regem zonas que não estão sob a competência de nenhum território nacional". ${ }^{35}$

A globalização da proteção do meio ambiente exige, portanto, uma maior compreensão dos mecanismos de proteção aos direitos humanos. Dessa forma, a Assembleia Geral (Resolução n. 37/189A, de 1982) e a Comissão de Direitos Humanos da ONU (Resoluções n. 1982/7, de 1982, e 1983/43, de 1983), ao analisarem o alcance do Pacto dos Direitos Civis e Políticos das Nações Unidas, consolidaram o entendimento de que o direito à vida engloba o exercício pleno dos direitos civis, políticos, econômicos, sociais e culturais a todos os indivíduos, povos, etnias, coletividades e grupos humanos. Nessa perspectiva, o direito ao acesso ao meio ambiente sadio se consolida como extensão do direito à vida. ${ }^{36}$

A vinculação entre direitos humanos e proteção ambiental é verificada, por exemplo, em dispositivos de tratados internacionais tais como: a) os arts. 35.3 e 55 do I Protocolo Adicional de 1977 às Convenções de Genebra de 1949, relativos à proibição de métodos ou meios bélicos causadores de graves danos ambientais; $b$ ) a Convenção das Nações Unidas de 1977 sobre a Proibição do Uso Militar ou Hostil de Técnicas de Modificação Ambiental; c) os $\$ \S 5^{\circ}$ e 20 e da Carta Mundial da Natureza de 1982; d) as Declarações de Cartagena sobre Refugiados de 1984 e de San José sobre Refugiados e Migrantes Forçados de 1994, que inserem ao rol de migrantes forçados protegidos pelo direito de asilo as vítimas de desastres ambientais; e) o art. 24, 2, alínea c, da Convenção das Nações Unidas sobre os Direitos da Criança de 1989, que determina aos Estados-partes investimentos em pesquisa, tecnologia, tratamento de água e fornecimento de alimentos saudáveis tendo em vista o combate à desnutrição e doenças bem como "os perigos e riscos da poluição ambiental”; f) e a Convenção sobre Acesso à Informação, Participação Pública e Acesso à Justiça nas Questões Ambientais de 1998, assinada por 35 Estados e a Comunidade Europeia, que incorporou aos seus dispositivos o Princípio 10 da Declaração do Rio relativo ao acesso à informação em processo decisório sobre tema ambiental. ${ }^{37}$

No âmbito dos sistemas internacionais de proteção aos direitos humanos, o art. 24 da Carta Africana dos Direitos Humanos e dos Povos de 1981 e o art. 11 do Protocolo Adicional à Convenção Americana sobre Direitos Humanos em Matéria de Direitos Econômicos, Sociais e Culturais de 1988, o chamado Protocolo de San Salvador, garantem expressamente o direito ao acesso ao ambiente sadio. Tais dispositivos, no entanto, não são capazes de, por si só, assegurarem a proteção ao meio ambiente. Isso porque apenas os direitos civis, políticos, econômicos, sociais e culturais - em suma, aqueles definidos pela Declaração Universal de 1948 - estão ao alcance dos mecanismos de monitoramento dos sistemas de proteção aos direitos humanos da ONU e das organizações regionais. Por outro lado, os direitos de solidariedade 
definidos pela Declaração de Estocolmo de 1972 - como o acesso ao meio ambiente sadio - quando interpretados como forma de exercício de uma série de direitos individuais e coletivos, passam a ser plenamente reivindicáveis. ${ }^{38}$

Como bem afirma Carla Amado Gomes, essa vinculação traz o ônus de uma proteção ambiental pela "via reflexa" ou por "ricochete", ou seja, da impossibilidade de um bem ambiental ser protegido nos sistemas de proteção aos direitos humanos sem que se demonstre e prove suas inter-relações com violações aos direitos civis, políticos, econômicos, sociais e culturais. ${ }^{39}$

\section{I.2.2 A proteÇão ambiental pela Via Reflexa nos Sistemas Regionais DE PROTEÇÃo AOS DIREITOS HUMANOS}

A técnica da proteção ambiental pela via reflexa (ou "por ricochete") se desenvolve a partir da concepção de que dentro da estrutura do atual direito internacional do meio ambiente a proteção da biosfera mostra-se eficaz por intermédio da indireta, porém, necessária proteção dos seres humanos. ${ }^{40}$ Isso porque a concepção de que o meio ambiente por si só já configura um direito a ser protegido mostra-se pouco eficaz à medida que no âmbito internacional os chamados direitos de solidariedade estão envoltos em um sistema de monitoramento extremamente frágil. Segundo Cançado Trindade, há direitos "que simplesmente não podem ser reivindicados diante de um tribunal por seus sujeitos ativos (titulares)". ${ }^{41}$ Portanto, para que tal situação não ocorra ao meio ambiente, a abordagem mais apropriada caminha no sentido de se buscar um esverdeamento (ou greening) dos mecanismos de proteção aos direitos civis, políticos, econômicos, sociais e culturais já existentes. ${ }^{42}$

Assim, o direito ao meio ambiente adquire duas dimensões: uma individual e outra coletiva. No âmbito individual, a garantia ao meio ambiente sadio se faz presente nas relações verticais e horizontais. Por obrigatoriedade de garantias ambientais nas relações verticais devemos entender aquelas que envolvem o Estado e os indivíduos. Assim, a relação vertical envolve o convívio de um indivíduo ou grupos de indivíduos com instrumentos legais estatais voltados à proteção de recursos naturais e à garantia de direitos civis e políticos como o acesso à informação e a participação na gestão de bens ambientais. ${ }^{43}$

No âmbito horizontal, a proteção ao meio ambiente surge da aplicação do Drittwirkung ou third party effect. O Drittwirkung implica a eficácia dos direitos fundamentais não só na relação entre indivíduos e Estado, mas também no âmbito das relações entre particulares. O "esverdeamento" dos direitos civis e políticos resultaria, portanto, em um Drittwirkung ambiental, ou seja, no que Cançado Trindade explica como o "Drittwirkung da literatura jurídica alemã, incidente sobre a proteção dos direitos humanos e a proteção ambiental”, capaz de impor nas relações entre particulares de cunho contratual, trabalhista ou civilista a observância de normas que garantam às partes envolvidas o direito fundamental de estarem em contato com um ambiente sadio. ${ }^{44}$ 
Na dimensão coletiva da proteção ambiental, o meio ambiente humano transforma-se em bem comum, resultado do esverdeamento dos direitos econômicos, sociais e culturais. Tal dimensão tem implicado a tendência de se proteger grupos e coletividades em estado de vulnerabilidade decorrente da degradação ambiental. ${ }^{45}$

Nos sistemas interamericano e africano de proteção aos direitos humanos, a tendência de "esverdeamento" dos direitos fundamentais é evidenciada pelo art. 11 do Protocolo de San Salvador e pelo art. 24 da Carta Africana de Direitos do Homem, que inseriram expressamente a garantia de acesso ao ambiente sadio no rol de direitos fundamentais a serem protegidos. Já na Europa, o “esverdeamento” dos direitos fundamentais contrasta com a ausência de cláusulas protetivas ao meio ambiente na Convenção Europeia de Direitos Humanos. ${ }^{46}$

No entanto, em comparação com os demais sistemas regionais, a jurisprudência da Corte Europeia - ainda que de forma incipiente - tem se destacado na inserção da temática ambiental em questões relativas à proteção de direitos humanos. Do Caso Powell e Rayner v. Reino Unido em 1990, relativo a supostas violações à vida privada e ao direito de propriedade decorrentes dos incômodos da poluição sonora do aeroporto de Heathrow aos moradores do seu entorno ${ }^{47}$, até meados da primeira década do século XXI percebe-se que os posicionamentos da Corte Europeia passaram a acompanhar o movimento de greening ou "esverdeamento" do direito internacional. ${ }^{48}$

O greening do sistema europeu é primeiramente evidenciado com uma mudança de postura da Corte Europeia na análise de casos semelhantes. Como exemplo, em 1990 o desfecho do Caso Powell e Rayner deu-se com o entendimento da Corte de que os incômodos dos moradores dos arredores de Heathrow com os ruídos do principal aeroporto do Reino Unido não caracterizaram violações aos direitos de vizinhança e propriedade assegurados pela Convenção Europeia. ${ }^{49}$ Ocorre que em 2001 novamente a Corte deparou-se com reclamações à poluição sonora de Heathrow. Desta vez, em Hatton e outros contra o Reino Unido, a Corte concluiu que, em observância à Convenção Europeia, o Estado britânico tem o dever de implementar medidas voltadas ao equilíbrio entre o interesse econômico e o direito à saúde, à propriedade e à vida privada e familiar dos vizinhos do aeroporto. ${ }^{50}$

O segundo momento do greening do sistema europeu é marcado pela diversificação de casos entre a temática ambiental e a proteção de direitos humanos, em especial a dispositivos da Convenção Europeia ligados à proteção da vida privada e familiar. Nesse sentido, destacam-se os seguintes casos: a) López Ostra contra Espanha, em 1994, sobre os incômodos da família López Ostra com as emissões de gás sulfúrico de uma central de tratamento de água na cidade de Lorca; b) Anna Maria Guerra e outros contra Itália, em 1998, relativo ao vazamento de uma fábrica de químico na Manfredonia; c) Moreno Gómez contra Espanha, em 2004, sobre a poluição sonora de uma discoteca em Valência; d) Giacomelli contra Itália, em 2006, sobre um depósito de sucatas em Brascia sem licenciamento ambiental; e) Fadeïeva contra Rússia, em 2005, 
relativo à contaminação provocada por um centro siderúrgico; f) Öneryildiz contra Turquia, em 2002, que versou sobre as vítimas de uma explosão de gás metano no depósito de lixo de Ümraniye; g) Taskin e outros contra Turquia, em 2004, sobre o funcionamento irregular de uma mina de ouro em Ovacik; e h) Tatar contra a Romênia, em 2009, sobre um desastre ecológico provocado pela descarga de instalações de uma mina de ouro no rio Sasar. ${ }^{51}$

Assim, ainda que de forma incipiente, do barulho de uma boate em Valência à poluição do rio Sasar, de um vazamento químico na Itália a um depósito de lixo na Turquia, o sistema europeu gradativamente tem demonstrado uma notável capacidade de inserir à proteção aos direitos humanos uma considerável variedade de temas ambientais. ${ }^{52}$ Já no sistema interamericano, os casos de temática ambiental são majoritariamente relacionados às violações de direitos dos povos indígenas, quilombolas e de comunidades campesinas. Tal fenômeno tem explicação no brutal aumento das demandas do sistema econômico vigente por recursos naturais das grandes florestas e de áreas habitadas pelos povos tradicionais das Américas. ${ }^{53}$

\section{O GREENING DA CONVENÇÃO AMERICANA SOBRE DIREITOS HUMANOS}

O sistema interamericano de direitos humanos é composto de um conjunto de tratados que formam uma rede de proteção e monitoramento de políticas em prol de direitos humanos entre os Estados-membros da Organização dos Estados Americanos (OEA). Entre tais tratados destacam-se a Declaração Americana de Direitos e Deveres do Homem de 1948 e a Convenção Americana sobre Direitos Humanos de 1969 também conhecida como Pacto de San José da Costa Rica. A Convenção Americana sobre Direitos Humanos, além de elencar uma série de direitos civis e políticos a serem protegidos por seus Estados-partes, estabelece o funcionamento de dois órgãos que compõem o sistema interamericano: a Comissão e a Corte Interamericanas de Direitos Humanos.

Sediada em Washington, a Comissão Interamericana - composta por sete membros eleitos pela Assembleia Geral da OEA, vedada a participação de mais de um membro nacional de um mesmo Estado - é regulada pelos arts. 34 a 51 da Convenção Americana. O funcionamento da Comissão é também regulado a) pelo seu Estatuto, aprovado pela resolução AG/RES. 447 (IX-O/79), adotada pela Assembleia Geral da OEA, em seu Nono Período Ordinário de Sessões, realizado em La Paz, Bolívia, em outubro de 1979; e b) pelo seu Regulamento, aprovado pela própria Comissão em seu $137^{\circ}$ período ordinário de sessões, realizado de 28 de outubro a 13 de novembro de 2009.

Assim, todos os Estados membros da OEA por intermédio do artigo 106 da Carta e da Resolução AG/RES. 447 (IX-O / 79) reconhecem a Comissão Interamericana como um dos órgãos da Organização dos Estados Americanos. Ocorre que o 
fato de nove Estados-membros da OEA não terem ratificado a Convenção, faz com que a Comissão Interamericana tenha atuação ambivalente, funcionando (a) como órgão da OEA e da Convenção Americana, em relação a vinte e quatro Estados da OEA; e (b) somente como órgão da OEA, em relação aos nove Estados-membros de tal Organização que ainda não ratificaram a Convenção. ${ }^{54}$

Em relação aos Estados que não ratificaram a Convenção Americana e aos que não reconhecem a jurisdição da Corte Interamericana, a Comissão atua como órgão geral, devendo publicar/apresentar à Assembleia Geral da OEA informes em seu Relatório Anual a respeito da atuação de tais Estados no estabelecimento de políticas em prol dos direitos humanos. Em relação aos Estados-partes da Convenção Americana que reconhecem a competência contenciosa da Corte Interamericana, a Comissão atua como órgão processual, à medida que encaminha casos de violação dos dispositivos da Convenção à Corte Interamericana de Direitos Humanos. 55

Sediada em San José, Costa Rica, a Corte Interamericana de Direitos Humanos é composta de sete juízes de nacionalidades diferentes e com mandato de seis anos, eleitos em votação secreta na Assembleia Geral da OEA pelo voto da maioria absoluta dos Estados-partes da Convenção. Aos Estados-partes da Convenção que reconhecem sua competência contenciosa, a Corte funciona como órgão responsável pela análise de ações de responsabilidade internacional apresentada ou pelos Estados-partes ou pela Comissão Interamericana contra Estados que tenham violado dispositivos da Convenção Americana. ${ }^{56}$

Nesse sentido, a Convenção Americana não comporta em seu texto qualquer direito de cunho econômico, social ou cultural, menos ainda de cunho ambiental. Assim, para que questões de cunho ambiental sejam submetidas ao sistema interamericano, é preciso socorrer-se ao chamado greening ou "esverdeamento" - fenômeno que ocorre quando se tenta (e se consegue) proteger direitos de cunho ambiental nos sistemas regionais de direitos humanos, que são sistemas aptos (em princípio) a receber queixas ou petições que contenham denúncias de violação a direitos civis $e$ políticos. O que fazer então? Há técnicas e estratégias para que se submeta, com sucesso, uma questão ambiental no sistema regional interamericano, quando então se diz que o sistema "esverdeou-se".

\section{I A PRoteÇÃo do MEIO AMBiENTE POR MEIO DE INSTRUMENTOS da Convenção Americana sobre Direitos Humanos}

Cerca de três anos após o primeiro caso de temática ambiental ser analisado pela Comissão Interamericana - a Resolução n. 12/85 do povo Yanomami v. Brasil -, em 17 de novembro de 1988, o Protocolo Adicional à Convenção Americana sobre Direitos Econômicos, Sociais e Culturais, o chamado Protocolo de San Salvador, inseriu no rol de proteção da Convenção Americana uma série de direitos sociais como direitos ao trabalho, à organização sindical, à alimentação, à educação, acesso à cultura, proteção da 
família, à criança, aos idosos e aos deficientes. A proteção ao meio ambiente é assegurada por seu art. 11 nos seguintes termos: "1. Toda pessoa tem direito a viver em ambiente sadio e a contar com os serviços públicos básicos. 2. Os Estados-Partes promoverão a proteção, preservação e melhoramento do meio ambiente".

O acesso ao sistema interamericano de casos relativos ao "direito a um meio ambiente sadio" e à garantia dos direitos econômicos, sociais e culturais é regulado pelo art. 19.1 do Protocolo de San Salvador, que estabelece um mecanismo de envio à OEA por seus Estados-partes de relatórios sobre suas políticas sobre os citados temas. O art. 19.6, no entanto, estabelece limitações ao sistema de monitoramento por petições iniciais, ao impor que apenas casos "estabelecidos na alínea 'a' do artigo 8" (organização sindical) e "no artigo 13" (acesso a educação) poderão ser submetidos à Comissão ou à Corte.

Tais limitações não implicam o desamparo aos demais artigos do Protocolo de San Salvador. Ocorre que casos em torno de dispositivos diversos dos indicados pelo art. 19.6 para serem levados à Comissão ou Corte Interamericanas, deverão obrigatoriamente estar vinculados à necessidade de se proteger os direitos de organização sindical, de acesso à educação e/ou demais garantias da Declaração Americana de Direitos e Deveres e/ou da Convenção Americana sobre Direitos Humanos. Logo, ainda que dispositivos além do art. $8^{\circ}$, alínea $a$, e do art. 13, não possam ser diretamente invocados, os demais artigos do Protocolo de San Salvador - incluindo o art. 11 relativo à proteção ambiental - podem ser usados como normas de interpretação relativas ao cumprimento da Convenção Americana. ${ }^{57}$

\section{I. I A PROTEÇÃO AMBiENTAL POR MEIO DA GARANTIA}

DE DIREITOS CIVIS E POLÍticos

Conforme já falado, em comparação ao sistema europeu, o greening da Comissão e Corte Interamericanas tem passado longe de questões como a poluição sonora causada por uma boate ou por um aeroporto. Pelo contrário, a imensa maioria dos casos inerentes à temática ambiental no sistema interamericano é relativa a violações ao fundamental direito à vida das populações mais vulneráveis à expansão econômica sobre os recursos naturais: os povos indígenas, quilombolas e as comunidades campesinas das Américas. ${ }^{58}$

Tal constatação é confirmada pelo Relatório da Secretaria-Geral da Organização dos Estados Americanos (OEA) sobre Direitos Humanos e Meio Ambiente, de 4 de abril de 2002, ${ }^{59}$ que destaca como exemplos de proteção ambiental pela via reflexa a Resolução n. 12/85 do povo Yanomami v. Brasil ${ }^{60}$ e o caso da Comunidade Indígena Awas Tingni Mayagna (Sumo) contra a Nicarágua: ${ }^{61}$ os primeiros casos de temática ambiental analisados pela Comissão e Corte Interamericanas, respectivamente.

A Resolução n. 12/85, ao relacionar os impactos da construção de uma rodovia em território amazônico habitado pela etnia Yanomami a um rápido processo de violação dos direitos à vida, à saúde, à liberdade, à segurança e ao direito de residência do 
grupo indígena afetado, implicou não só a inédita abordagem (ainda que "por ricochete"62) da temática ambiental, mas evidenciou também que outros grupos em situação semelhante de vulnerabilidade poderiam socorrer-se do sistema interamericano. ${ }^{63}$

Entre os casos analisados ou em análise pela Comissão Interamericana supervenientes à Resolução n. 12/85, destacam-se: a) a Solução Amistosa do Caso Mercedes Julia Huentes Beroiza, relativa à desapropriação de cinco mulheres indígenas de suas terras tradicionais para a construção de uma central hidroelétrica em Alto De Bio Bio, VIII Região do Chile; b) Comunidades Indígenas Maia de Toledo v. Belize, em torno da concessão pelo Estado de terras indígenas para exploração madeireira sem prévio consentimento das etnias afetadas; c) Povo Indígena Kichwa de Sarayacu e seus membros v. Equador, relativo à concessão estatal de terras indígenas para exploração de petróleo sem que os Kichwas fossem consultados; d) o Caso San Mateo Huanchor v. Peru, em que uma mineradora utilizou-se dos arredores de comunidades campesinas como depósito de lixo tóxico; e) Comunidades Indígenas Ngöbe e seus membros do Vale do Rio Changuinola v. Panamá, em que Estado é acusado de autorizar a construção de uma hidroelétrica em terras ancestrais Ngöbe sem prévia consulta à população afetada; f) a Petição Inicial n. 1.413/05 do Povo Inuit contra os Estados Unidos, sobre as responsabilidades do governo americano em relação aos impactos do aquecimento global no modo de vida do povo esquimó; e g) a solicitação da Medida Cautelar MC-382/10 das Comunidades tradicionais da bacia do Rio Xingu pleiteando a paralisação das obras da hidroelétrica de Belo Monte, em Altamira, Pará. ${ }^{64}$

Seguindo o exemplo da Comissão Interamericana, a temática ambiental ao ser abordada nas decisões da Corte Interamericana é, em sua maioria, igualmente relativa à proteção de direitos de comunidades indígenas ou tradicionais. A primeira decisão da Corte nesse sentido versou sobre a concessão irregular de exploração madeireira em terras indígenas em Comunidade Mayagna (Sumo) Awas Tingni v. Nicarágua. ${ }^{65}$ Após o caso da Comunidade Mayagna (Sumo) Awas Tingni, a Corte deparou-se ainda com os seguintes casos: a) Moiwana v. Suriname, relativo à inércia estatal em promover investigações e punir os responsáveis por um massacre promovido pelo Exército em novembro de 1986 contra a comunidade N'djuka Maroon de Moiwana, que resultou na morte de mais de 40 indígenas entre eles, homens, mulheres e crianças; b) Comunidade Indígena Yakye Axa v. Paraguai, sobre o não reconhecimento de terras tradicionais da etnia Enxet-lengua e a vulnerabilidade alimentícia, médica e sanitária em que se encontravam os indígenas de Yakye Axa; c) Comunidade Indígena Sawhoyamaxa v. Paraguai, também relativo ao não reconhecimento de terras tradicionais do povo Enxet-lengua, desta vez em Sawhoyamaxa; e d) Caso Povo Saramaka. v. Suriname, em que novamente uma demanda em torno do não reconhecimento de terras tradicionais foi levada à esfera interamericana. ${ }^{66}$

Tais casos demonstram que, a exemplo do sistema europeu, a Corte Interamericana tem demonstrado um notável esforço de vincular temas ambientais a questões de 
proteção aos direitos humanos. Outro aspecto do processo de greening da Corte Interamericana é a revelação de posicionamentos que fatalmente se desenvolveram a partir da constante análise de casos que dificilmente seriam abordados de forma comum ou rotineira em um sistema de proteção a direitos humanos que não estivesse inserido nas especificidades regionais das Américas. Como exemplo, a Corte Interamericana, em Awas Tingni v. Nicarágua, ao concluir que os prejuízos ambientais da exploração madeireira irregular em território tradicional de grupos indígenas implicaram violações ao direito de propriedade das comunidades afetadas, demonstrou que a proteção ao direito de propriedade garantido pelo art. 21 da Convenção Americana se estende a) à percepção ocidental do direito de propriedade, similar a uma espécie de "commodity de mercado"67 relacionada ao direito de um indivíduo "usar, gozar e dispor de seus bens", 68 e b) ao conceito de propriedade comunal dos povos indígenas, exercido pela garantia de tais povos utilizarem-se dos recursos naturais de suas terras tradicionais como forma de manutenção de seus hábitos culturais como, religião, práticas agrícolas, a caça, a pesca e os modos de vida de suas respectivas comunidades. ${ }^{69}$

Partindo da perspectiva indígena de propriedade (inerente à forte ligação de tais povos com a natureza), os casos supervenientes a Awas Tingni mostram que as decisões da Corte Interamericana têm conferido um alcance cada vez mais amplo aos dispositivos da Convenção Americana. Em Moiwana v. Suriname, por exemplo, o sofrimento psicológico de indígenas afastados de suas terras tradicionais, por se sentirem perturbados pela "ira dos espíritos dos mortos" de uma chacina promovida pelas forças armadas surinamesas contra a etnia N'djuka Maroon, fez com que a Corte desenvolvesse o conceito de dano "espiritual” decorrente de violações de dispositivos da Convenção Americana relativos ao direito a integridade pessoal, garantia e proteção judicial, direito de propriedade e direito de circulação e residência. ${ }^{70}$

Em Yakye Axa v. Paraguai, a Corte fortaleceu o entendimento de que o direito à vida não se restringe ao direito de sobrevivência em si, mas se estende à promoção de uma vida com dignidade, exercida de forma plena com o acesso aos benefícios da cultura, à saúde, alimentação, educação e ao meio ambiente sadio. ${ }^{71}$ Em Sawhoyamaxa v. Paraguai ${ }^{72}$ e Saramaka v. Suriname, ${ }^{73}$ a ineficácia ou inexistência de mecanismos da legislação interna dos Estados demandados em garantir aos povos indígenas o direito de pleitearem juridicamente a propriedade de suas terras fez com que a Corte destacasse a violação do direito de reconhecimento de personalidade jurídica, como forma de privação dos povos indígenas do contato com a terra e seus recursos naturais.

O amplo domínio de casos relativos aos povos indígenas, no entanto, não implica limitação da proteção ambiental pela via reflexa no sistema interamericano a casos relacionados a comunidades tribais, tradicionais ou campesinas. A Comissão Interamericana, por exemplo, em 2003, analisou o Caso Parque Natural Metropolitano do Panamá, relativo a uma petição enviada pelo Sr. Rodrigo Noriega tratando dos supostos 
danos da construção de uma via expressa em uma área de reserva ecológica. ${ }^{74} \mathrm{E}$ em 2009 a Comissão deparou-se com o primeiro caso relativo à contaminação do meio ambiente e violações de direitos humanos de comunidades não indígenas. Trata-se dos efeitos da poluição de um complexo metalúrgico na cidade de La Oroya, com 30 mil habitantes e a cerca de $175 \mathrm{~km}$ de Lima, Peru. ${ }^{75}$

$\mathrm{Na}$ Corte Interamericana, a única decisão (até o presente momento) em torno de temática ambiental não relacionada a grupos indígenas ou povos tradicionais foi a proferida no caso Claude Reyes e outros v. Chile, relativo à negativa do Estado em fornecer dados a respeito de um projeto de desflorestamento a três cidadãos chilenos. Nesse caso, o direito de liberdade de expressão previsto no art. 13 da Convenção teve seu alcance ampliado à necessidade estatal de garantir o acesso à informação, notadamente em questões ambientais. ${ }^{76}$

A Comissão e Corte Interamericanas, ao analisarem também temas ambientais de comunidades não indígenas, sinalizam que a proteção ambiental por meio dos mecanismos e princípios da Convenção Americana de Direitos Humanos engloba a ampla garantia de direitos de "qualquer pessoa". Em outras palavras, a proteção ambiental no sistema interamericano surge do exercício de "escrever verde por linhas tortas", 77 ou seja, não da preocupação ambiental em si, mas da pragmática necessidade de se proteger dispositivos da Convenção Americana como, por exemplo, o art. 8.1 sobre garantias judiciais, o art. 12 sobre liberdade de religião, o art. 13 sobre liberdade de expressão ou, até mesmo, o art. 21 relativo ao direito de propriedade. ${ }^{78}$

Assim, a proteção ambiental no sistema interamericano tem evidenciado a necessidade de estar vinculada à demonstração de violações a dispositivos da Declaração ou Convenção Americanas. Como destaca Carla Amado Gomes, essa vinculação traz o ônus de uma proteção ambiental pela "via reflexa" ou por "ricochete", ou seja, da impossibilidade de um bem ambiental ser protegido sem que suas inter-relações com violações aos direitos civis, políticos, econômicos, sociais e culturais sejam devidamente demonstradas e comprovadas. ${ }^{79}$

No entanto, o "escrever verde por linhas tortas" mostra-se o mecanismo mais apropriado ao presente momento histórico em que o direito internacional do meio ambiente não conta com organismos similares ao sistema das Nações Unidas, como o Comitê de Direitos Econômicos Sociais e Culturais ou o Conselho de Direitos Humanos, por exemplo. Tal constatação reforça a necessidade de "esverdeamento" ou greening dos sistemas de proteção aos direitos humanos existentes, vinculando a causa ambiental ao cumprimento de seus dispositivos. ${ }^{80}$

\section{I.2 Estratégias de SUbmissão de CASOS Ambientais Ao SISTEMA INTERAMERicANo} Além da necessária vinculação de temas ambientais a dispositivos da Convenção Americana, compõe o rol de elementos estratégicos relevantes à busca pela chamada proteção ambiental pela "via reflexa" ou por "ricochete", a compreensão das formas de 
submissão de um caso ao sistema interamericano. ${ }^{81}$ Nesse sentido, o envio de um caso à Comissão Interamericana ocorre por meio: a) das comunicações interestatais; $b$ ) das petições individuais; e c) das solicitações de outorga de medidas cautelares. ${ }^{82}$

A comunicação interestatal (art. 45 da Convenção) permite aos Estados levar à Comissão casos relacionados à violação de direitos humanos por ação ou omissão de outro Estado-parte. No entanto, a aplicação da comunicação interestatal é vinculada à adoção de cláusula facultativa e, como apenas dez Estados da OEA reconhecem a competência da Comissão para receber e examinar as comunicações interestatais, a análise de petições individuais tem se consolidado como atribuição principal da Comissão Interamericana. ${ }^{83}$

O direito de acesso à Comissão pela via de petições, vale realçar, não se vincula a nenhuma cláusula facultativa, e, portanto, todos Estados da OEA, ao reconhecerem a Convenção e/ou os estatutos e regulamentos da CIDH, estão automaticamente submetidos ao processo de petições individuais (perante a Comissão). O amplo alcance da legitimidade ativa das petições iniciais - garantida a "qualquer pessoa", "grupo de pessoas" ou "entidade não governamental" reconhecida por algum Estado-Membro da OEA - é, entretanto, limitado pelos seguintes fatores: a) por considerar que "pessoa é todo ser humano", para o sistema interamericano, ao contrário do europeu, pessoas jurídicas como empresas ou ONGs não podem ser vítimas de violações, embora seus integrantes o possam; b) somente Estados podem ser declarados responsáveis pelas ações ou omissões de outros entes violadores de direitos humanos; c) peticionários e vítimas devem ser necessariamente individualizados, sob pena da petição em nome de grupos difusos de pessoas ou de maneira abstrata implicar a sua inadmissibilidade e encerramento do processo perante a Comissão; d) assim, caso não seja possível identificar a vítima, deve-se ao menos indicar a possibilidade de fazê-lo. ${ }^{84}$

A petição deve ainda ser apresentada dentro do prazo de seis meses, a partir da data em que o presumido prejudicado em seus direitos tenha sido notificado da decisão definitiva, desde que sua matéria não seja também objeto de outro processo de solução internacional. ${ }^{85} \mathrm{O}$ art. 46.1, alínea $a$, da Convenção, determina ainda outro requisito de admissibilidade: o prévio esgotamento dos recursos internos. ${ }^{86} \mathrm{~A}$ regra do esgotamento dos recursos internos, no entanto, não é aplicada nas seguintes situações: a) ausência na legislação interna do Estado de que se tratar, do devido processo legal para a proteção do direito ou direitos que se alegue tenham sido violados; $b$ ) não se houver permitido ao presumido prejudicado em seus direitos o acesso aos recursos da jurisdição interna, ou houver sido ele impedido de esgotá-los; e c) quando houver demora injustificada na decisão sobre os mencionados recursos. ${ }^{87}$

Em questões ambientais, ganha destaque o caso Comunidades Indígenas Maias v. Belize, em que o Estado demandado por ter permitido a extração de madeira e petróleo em áreas tradicionalmente ocupadas por comunidades indígenas maias argumentou que os representantes daquelas comunidades não se utilizaram dos mecanismos 
judiciais domésticos apropriados para esgotar os recursos da jurisdição interna. Em resposta, a Comissão declarou que o Estado de Belize, além de não ter proporcionado às comunidades indígenas o correto e efetivo acesso ao seu sistema jurídico, utilizou-se de mecanismos ineficientes que trouxeram demora injustificada à solução da demanda. ${ }^{88}$

A criteriosa verificação dos requisitos de admissibilidade da petição inicial, principalmente no que diz respeito à analise do esgotamento ou eficácia dos recursos disponíveis na jurisdição interna, é salutar à medida que incentiva o funcionamento e os debates em torno da eficiência e do aperfeiçoamento dos sistemas nacionais. No entanto, para casos de iminente risco de violações irreparáveis a direitos humanos, os rigorosos requisitos de admissibilidade das petições iniciais podem implicar prejuízos à proteção de direitos. Por isso, em situações de gravidade e urgência, a Comissão poderá, por iniciativa própria ou a pedido da parte, solicitar que um Estado adote medidas cautelares para prevenir danos irreparáveis a pessoas ou a organização, grupo ou comunidade de pessoas determinadas ou determináveis, que se encontrem sob sua jurisdição, ou ao objeto do processo relativo a uma petição ou caso pendente. 89

Em razão do caráter de urgência das medidas cautelares, não há falar na necessidade de esgotamento dos recursos de jurisdição interna, mas é necessário demonstrar que a situação de risco iminente tenha sido denunciada perante as autoridades locais competentes. Caso as autoridades locais não tenham sido acionadas, deverão ser demonstrados os motivos que justificaram o não cumprimento de tal requisito. ${ }^{90}$ A Comissão, antes de solicitar a adoção de medidas cautelares, pedirá informações ao Estado, salvo quando o caráter de urgência justificar a imediata outorga das medidas. ${ }^{91}$

A solicitação de medidas cautelares não tem o intuito de obter qualquer pré-julgamento do mérito da questão, mas, sim, de aplicar medidas temporárias com maior celeridade. Havendo necessidade, os efeitos das medidas cautelares podem ser prorrogados e se, mesmo assim, o Estado não as observar, a Comissão poderá requisitar à Corte a concessão de medidas provisórias. ${ }^{92}$ Vale lembrar que os mecanismos de medidas cautelares e provisórias simplesmente não existem no sistema europeu de direitos humanos. Não por acaso, enquanto na Corte Europeia os pleitos mais comuns são relativos ao acesso equitativo e julgamento justo, os pleitos que lideram em absoluto as lides da Corte Interamericana são relacionados à proteção do direito fundamental à vida. ${ }^{93}$

Nesse sentido, casos de degradação ambiental têm potencial capacidade de demonstrar situações em que direitos fundamentais encontram-se sob risco de danos irreparáveis. Como exemplo, o caso Povo Indígena Kichwa de Sarayacu e seus membros v. Equador, relativo à concessão de terras indígenas para exploração petrolífera, sem anuência da comunidade afetada, foi marcado por episódios como destruição de 
florestas, interrupção do curso de um rio, uso de explosivos em terras tradicionais, além de ataques de arma de fogo, agressões, ameaças, prisões ilegais, abusos sexuais e torturas contra os Kichwa. Para conter tais horrores, entre 2003 e 2010, Comissão e Corte Interamericanas encaminharam à República do Equador três medidas cautelares e quatro medidas provisórias. ${ }^{94}$

Além dos instrumentos da Convenção Americana e do Regulamento da Comissão Interamericana relativos ao acesso e à admissibilidade de casos ao sistema interamericano, dois outros dispositivos da Convenção mostram-se importantes elementos estratégicos: a) o procedimento de solução amistosa; e b) a adoção de cláusula pro homine. O procedimento de solução amistosa, nos moldes do art. $48, f$, deve ser proposto pela Comissão em qualquer fase do processo e mostra-se a via mais rápida ao término de um litígio. A adoção de cláusula pro homine, por sua vez, é garantida pelo art. 29, b, da Convenção, que permite a aplicação de dispositivos do direito interno e de outros tratados ratificados pelo Estado demandado, caso estes venham a ser mais benéficos ao ser humano. Em casos de prejuízos de direitos de populações indígenas, por exemplo, tem sido comum a adoção de dispositivos da Convenção n. 169 da OIT sobre Povos Indígenas e Tribais pela Comissão e Corte. ${ }^{95}$

\subsection{CONTRIBUiÇÕES E DESAFIOS DO GREENING NO SISTEMA INTERAMERICANO}

O processo de greening do sistema interamericano tem produzido um alcance maior dos dispositivos da Convenção Americana na percepção das inter-relações entre a temática ambiental e a proteção aos direitos humanos. Tal percepção parece mais nítida à Corte Europeia de Direitos Humanos, que, da poluição sonora do aeroporto de Heathrow ao barulho de uma boate em Valência, da poluição do rio Sasar a um vazamento químico na Itália, passando pela explosão de um depósito de lixo na Turquia, tem demonstrado enorme criatividade em vincular os casos de degradação ambiental a violações de dispositivos da Convenção Europeia (que, por sua vez, não possui sequer um artigo que faça menção ainda que indireta ao meio ambiente). ${ }^{96}$

Em que pese a grande maioria dos casos de temática ambiental analisados pela Comissão e Corte Interamericanas versar sobre questões indígenas e dos povos tradicionais da América, os casos Comunidade de La Oroya v. Peru, relativos aos efeitos da poluição de um complexo metalúrgico em uma cidade de 30 mil habitantes, e Claude Reyes e outros v. Chile, sobre a negativa do Estado em informar três cidadãos sobre os detalhes de um projeto de desflorestamento, bem sinalizam ser plenamente possível o diálogo entre os dispositivos da Convenção Americana e uma maior diversidade de temas ambientais. ${ }^{97}$

Assim, da mesma forma que a poluição dos complexos metalúrgicos ou o cerceamento do acesso à informação sobre o impacto ambiental de determinados empreendimentos trazem em si a percepção de violações de direitos humanos, há de se reconhecer, por exemplo, que desastres ambientais decorrentes de alterações climáticas 
provocadas pelo crescente aumento da temperatura na Terra também implicam violações a direitos fundamentais. ${ }^{98}$ Nesse sentido, torna-se emblemática a pioneira Petição n. 1.413/05 que versa sobre os efeitos nocivos do aquecimento global ao meio ambiente do Círculo Polar Ártico e ao modo de vida do povo esquimó Inuit. Ao longo de 175 páginas, os peticionários demonstraram as inter-relações entre a inércia dos Estados Unidos em reduzir a emissão de gases de efeito estufa e violações a direitos do povo Inuit assegurados pela Declaração Americana. ${ }^{99}$ No entanto, a Petição n. 1.413/05 mereceu da Comissão Interamericana uma resposta de dois parágrafos, sem maiores explicações, dizendo que "as informações fornecidas não nos permite determinar se o fatos alegados tendem a caracterizar uma violação a direitos protegidos pela Declaração Americana”. 100

Tal episódio indica que o diálogo entre os artigos da Declaração e da Convenção Americanas e uma variedade maior de temas ambientais ainda não chegou à sua maturidade no sistema interamericano. No entanto, o inédito encaminhamento da Petição n. 1.413/05, com suas interconexões bem demonstradas entre a degradação ambiental causada pelo aquecimento global e violações de direitos fundamentais do povo Inuit, por si só, representa o fortalecimento do diálogo entre os mais variados temas ambientais e os sistemas regionais de proteção aos direitos humanos. Esse diálogo compõe um elemento vital à solução das lides, que é o atendimento das demandas do chamado "direito pós-moderno".

\subsection{A CRESCENTE PERCEPÇÃo dos Elementos DA PÓS-MODERNIDAde NAS RELAÇÕES JURÍDICAS}

Segundo Erik Jayme, a pós-modernidade encontra-se caracterizada pela valoração do pluralismo, dos sentimentos humanos, das normas narrativas e da intensa comunicação intercultural. ${ }^{101}$ A valoração do pluralismo é verificada com o reconhecimento de que as diferentes concepções culturais devem também ser objeto de proteção. Tal valoração é fruto do debate entre o universalismo e relativismo cultural, bem assim do temor de que a adoção de uma moral universal pudesse consistir no reconhecimento da supremacia de uma determinada cultura sobre as outras. ${ }^{102}$ Assim, a atuação não só das Cortes Internacionais bem como dos Tribunais nacionais deve ser pautada não pela "superposição de propostas", mas sim pelo desenvolvimento de um processo "conflitivo" e "discursivo" de "encruzamento" de ideias e de diálogo entre as diversidades culturais. ${ }^{103}$ Erik Jayme explica que essa necessidade de diálogo com as múltiplas concepções culturais compõe as características da cultura pós-moderna e de "uma idade de luz" marcada pela tolerância para com os outros e pelo respeito às diferenças. ${ }^{104}$

Sob a óptica do "retorno ao sentimento", o direito atual deve, portanto, atentarse para o fato de que as ações humanas não se restringem à ideia de utilidade ou às metas de atendimento de demandas econômicas. Pelo contrário: os valores "inerentes 
à alma" também se inserem no rol dos direitos fundamentais contemporâneos. ${ }^{105}$ Nesse sentido, poucos exemplos mostram-se mais comoventes do que os relatos de membros da etnia N'djuka Maroon que sobreviveram a um ataque do exército surinamês contra indígenas da comunidade Moiwana, em 1986. Passadas quase duas décadas após a matança, membros N'djuka Maroon explicaram à Corte Interamericana que não podiam regressar às suas terras ancestrais porque se sentiam atormentados pelos "espíritos vingadores" ofendidos com as injustiças em torno do caso, e por não terem sido realizados os rituais de "purificação da terra" essenciais para que os vivos que almejassem viver em Moiwana buscassem a reconciliação com os espíritos dos mortos no massacre. ${ }^{106}$ Tais relatos fizeram com que a Corte desenvolvesse o conceito de dano "espiritual”, inerente ao sofrimento emocional e psicológico das vítimas de violações a direitos fundamentais. Segundo a Corte, em Moiwana v. Suriname, os sobreviventes do massacre foram vítimas de danos espirituais decorrentes de violações a dispositivos da Convenção Americana relativos ao direito a integridade pessoal (art. 5.1), garantia e proteção judicial (arts. $8^{\circ}$ e 25), direito de propriedade (art. 21) e direito de circulação e residência (art. 22). ${ }^{107}$

Outro elemento pós-moderno verificado no sistema interamericano é a valoração das normas narrativas, por meio da utilização de valores contidos em normas de soft law no auxílio à compreensão do alcance de normas de hard law. Embora as normas de soft law careçam de "valor propriamente jurídico" por possuírem "valor normativo menor do que as normas tradicionais", nem por isso deixam de ter significância no direito internacional atual. ${ }^{108}$ Ao revés, os valores programáticos das normas de soft law são detentores de significância ainda maior, uma vez que, por serem estruturados pelo princípio da boa-fé, se inserem nas relações jurídicas embasadas em normas de hard law como as relações contratuais, por exemplo. ${ }^{109}$ Assim, o direito na pós-modernidade por meio da "emergência das normas narrativas" atende à necessidade de não apenas indicar a função de suas normas, mas também os seus valores. ${ }^{110}$

Em Claude Reyes e outros v. Chile, a Corte Interamericana ao dispor que o direito de liberdade de expressão contido no art. 13 da Convenção relaciona-se com o direito de acesso à informação estabelecido pelo Princípio 10 da Declaração do Rio de 1992, consequentemente, utilizou-se da valoração de normas narrativas de soft law para interpretar o alcance de uma norma de hard law.

A comunicação intercultural - outro elemento da pós-modernidade - mostra-se presente em decisões marcadas pelo diálogo das fontes, ou seja, da busca pela solução de uma lide não só pela aplicação de uma única fonte de direito, mas daquela mais favorável à proteção dos direitos humanos, independentemente do fato de tal norma se fazer presente em um tratado internacional ou em normas do direito interno. ${ }^{111}$

Em Comunidade Indígena Sawhoyamaxa v. Paraguai, o diálogo das fontes foi utilizado à medida que a Corte Interamericana, para decidir-se sobre a demarcação de terras indígenas, analisou dispositivos da Convenção Americana, da Convenção n. 169 da 
OIT sobre os Povos Indígenas e Tribais, e de normas constitucionais e infraconstitucionais do direito interno paraguaio. ${ }^{112}$ A mesma técnica foi utilizada em Saramaka v. Suriname, em que a Corte verificou que, apesar de as leis internas surinamesas não versarem sobre o direito de propriedade comunal dos povos tribais, o Estado demandado havia incorporado ao seu ordenamento jurídico os Pactos Internacionais das Nações Unidas dos Direitos Civis e Políticos e dos Direitos Econômicos, Sociais e Culturais, que garantem direitos fundamentais (como do direito de propriedade) a "todos os povos", 113 sem qualquer distinção. Assim, a Corte concluiu que o não reconhecimento do direito de propriedade comunal dos Maroon Saramakas implicava violação ao art. 21 da Convenção Americana, relativo ao direito de propriedade. ${ }^{114}$

O diálogo entre os artigos da Convenção Americana e as normas de tratados internacionais e do direito interno, visando à aplicação da norma mais benéfica ao ser humano, é garantido pelo art. 29, b, da Convenção Americana, que não permite qualquer interpretação tendente a limitar o alcance dos dispositivos não só da própria Convenção como também de outros tratados internacionais que seja o Estado-parte.

A técnica de interpretação pro homine garantida por cláusulas dialógicas como o art. 29, b, da Convenção Americana, representa uma alternativa ao "monismo clássico", incapaz de diferenciar "as normas internacionais pelo seu conteúdo", e que, por isso, quando em jogo o tema direitos humanos, cede lugar ao "diálogo" entre as fontes de proteção internacional e interna, a fim de escolher qual a "melhor norma" a ser aplicada no caso concreto. 115

A adoção de um monismo mais dialógico ${ }^{16}$ e menos fechado implica grande contribuição do sistema interamericano no fortalecimento do direito pós-moderno, à medida que o diálogo entre as fontes mais heterogêneas, das convenções internacionais aos sistemas nacionais, possibilita aos "juízes coordenar essas fontes escutando o que elas dizem”. ${ }^{117}$ Em outras palavras, a utilização por parte da Comissão e da Corte Interamericanas do "diálogo das fontes” em casos de temática ambiental constitui uma grande contribuição do sistema interamericano, não apenas à solução de lides no âmbito internacional, mas principalmente às relações jurídicas de âmbito interno, uma vez que o estudo e a análise de tais técnicas interpretativas devem servir de incentivo aos Estados-partes da Convenção Americana na adoção em seus respectivos sistemas jurídicos de posturas mais eficazes à solução de conflitos e à proteção do meio ambiente e dos direitos humanos.

\subsubsection{Efeitos E Desafios do GREENING Dos DiReitos humanos}

AO DIREITO INTERNO BRASILEIRO

A principal característica dos sistemas internacionais de proteção aos direitos humanos é a atuação subsidiária ou complementar ao direito interno. Ou seja, o sistema interamericano pressupõe que a primazia pela defesa a direitos fundamentais pertence justamente aos Estados. Por isso, os sistemas de proteção aos direitos humanos em 
nenhum momento rivalizam com a jurisdição estatal, mas a auxiliam indicando princípios a serem adotados no âmbito interno com intuito de promover uma finalidade comum aos Estados e à comunidade internacional: a proteção de forma mais célere e efetiva de direitos fundamentais. ${ }^{118}$

Assim, da mesma forma que o art. 29, b, da Convenção Americana determina que suas disposições devam ceder à lei nacional ou a outros tratados ratificados por um Estado quando tais dispositivos se mostrarem mais benéficos ao ser humano, devem também os Estados, no seu âmbito interno, se dedicarem à aplicação dos dispositivos da Convenção quando se mostrarem mais eficazes à proteção desses mesmos direitos que a sua legislação interna. 119

Como exemplo desse diálogo que deve ocorrer entre as normas de direito interno e internacional, o STF, em 3 de dezembro de 2008, ao julgar o RE n. 466.343/SP, entendeu que em que pese a própria Constituição brasileira prever em seu art. $5^{\circ}$, LXVII, a prisão do depositário infiel, tal modalidade de prisão foi considerada inconstitucional (inconvencional) uma vez que contrariava o art. 7.7 da Convenção Americana. ${ }^{120}$ Em 16 de dezembro de 2009, o STF aboliu de vez tal forma de coerção pessoal ao editar a Súmula Vinculante n. 25, que estabeleceu ser "ilícita a prisão civil do depositário infiel, qualquer que seja a modalidade do depósito”. ${ }^{121}$

Além do diálogo das fontes, percebe-se que a exemplo da postura da Comissão e Corte Interamericanas, a valoração do pluralismo e do "sentimento humano" pode e deve inserir-se ao direito interno. ${ }^{122}$ É o que ocorre quando os tribunais nacionais passam a destacar a percepção dos chamados danos extrapatrimoniais ambientais, ou seja, a percepção de que a deterioração do meio ambiente gera não só prejuízos aos ecossistemas ou à economia, implicando também em sofrimento e abalo emocional àqueles que se encontram privados do contato com o ambiente sadio. Exemplo disso é o acórdão proferido pelo Tribunal de Justiça do Paraná, nos autos do Reexame Necessário n. 120.571-2, em que o Município de Mandirituba, ao lançar esgotos em uma galeria pluvial, causou mortandade de peixes em um riacho, e, por sua vez, a falência de um estabelecimento empresarial que se utilizava das águas do riacho para piscicultura e área de pesque-pague. O Tribunal, ao condenar o Município ao pagamento de reparações e indenizações decorrentes do dano ambiental, destacou que, além dos prejuízos econômicos, foi o proprietário do estabelecimento também vitimado por sofrimento, abalo emocional e quadro de depressão decorrente da degradação ambiental. ${ }^{123}$

Em que pesem as contribuições ao direito interno feitas pelo sistema interamericano de direitos humanos, por mais contraditório que possa parecer, a compreensão da importância dos tratados internacionais no âmbito interno não atingiu ainda a sua maturidade no direito brasileiro. Vale dizer que desde 1992, quando por meio do Decreto n. 678 o Brasil se inseriu no rol de Estados-partes da Convenção Americana, até o ano de 2008 - com a publicação da obra Comentários à Convenção Americana sobre 
Direitos Humanos ${ }^{124}$-, nenhum "estudo sistematizado" se dedicou especificamente entre nós ao estudo do texto do chamado Pacto de San José. ${ }^{125}$ Da mesma forma, em que pese o Brasil por meio do Decreto Legislativo n. 89 de 1998 ter reconhecido a competência contenciosa da Corte Interamericana, a sistemática de processamento de um Estado à Comissão e Corte Interamericanas não tem sido estudada na maior parte das universidades brasileiras.

O resultado de tal cenário não poderia ser outro se não a quase total ausência de referências aos dispositivos da Convenção Americana nos pedidos ou em decisões judiciais, além da constatação de que os processualistas brasileiros têm se restringido à letra fria do Código de Processo Civil, como se os conflitos de interesses em que uma pessoa possa estar envolvida não pudesse jamais ultrapassar as fronteiras do Estado onde ela se encontra.

Também contribui para a pouca percepção da importância da Convenção Americana o fato de a Constituição brasileira não conter dispositivos acerca das relações entre o direito interno e o direito internacional, inicialmente apenas se limitando em dispor, em seu art. $5^{\circ}, \S 2^{\circ}$, que os direitos previstos no texto constitucional não excluem outros decorrentes dos tratados em que a República Federativa do Brasil seja parte. Posteriormente, como decorrência dos avanços no campo do direito constitucional internacional no Brasil (após a EC n. 45/2004) é que se inseriu no texto constitucional dispositivo permissivo da "equivalência de emenda constitucional" aos tratados de direitos humanos aprovados pelo Congresso Nacional em turno duplo nas duas Casas e quórum equivalente ao da aprovação de uma emenda constitucional $\left(\operatorname{art} .5^{\circ}, \S 3^{\circ}\right) .126$

Ao estabelecer que os tratados internacionais de direitos humanos podem ser de duas espécies, a Constituição brasileira faz com que os tratados aprovados pelo quórum do art. $5^{\circ}, \S 3^{\circ}$, passem a se equivaler às emendas constitucionais se diferenciando, no âmbito interno, dos demais tratados de direitos humanos por três motivos: a) primeiro, passarão a reformar a Constituição; $b$ ) não poderão ser denunciados; e $c$ ) poderão ser objeto de controle concentrado de convencionalidade, por meio de propositura de ações do controle abstrato (como ADIn, ADECON e ADPF) a fim de invalidar normas infraconstitucionais com ele incompatíveis. ${ }^{127}$

Os $\S \S 2^{\circ}$ e $3^{\circ}$ do art. $5^{\circ}$ da Constituição brasileira são bem menos explícitos no intuito de assegurar o cumprimento dos termos dos tratados internacionais de direitos humanos no âmbito interno quando comparados com dispositivos constitucionais de outros Estados-partes da Convenção Americana. O art. 23 da Constituição da Venezuela, por exemplo, deixa claro que os tratados internacionais de direitos humanos, além de "hierarquia constitucional", podem vir a adquirir natureza supraconstitucional caso "contenham normas mais favoráveis às estabelecidas" pela Constituição. O inciso XXII do art. 75 da Constituição da Argentina, por sua vez, insere a Convenção Americana em um rol de tratados com hierarquia expressamente 
constitucional, que só podem ser denunciados mediante prévia aprovação de dois terços dos membros do Legislativo. Ademais, Guatemala, Nicarágua, Peru, Chile e Colômbia também incorporaram em seus respectivos textos constitucionais regras bastante nítidas sobre a hierarquia dos tratados internacionais de direitos humanos nos seus ordenamentos internos. ${ }^{128}$

Como reflexo da ausência na Constituição brasileira de dispositivos mais nítidos (como os dos seus vizinhos latino-americanos) acerca da eficácia interna das normas de tratados internacionais, entre 1992 - ano da entrada em vigor da Convenção Americana no Brasil ${ }^{129}$ - e 2008, os Tribunais brasileiros demonstravam enorme dificuldade em compreender os efeitos no plano interno dos dispositivos do Pacto de San José. Isso porque, em 1992, depois de transcorridos, portanto, quatro anos da promulgação da Constituição, o Congresso Nacional ao aprovar a Convenção Americana (ao que tudo indica) não percebeu que o art. 7.7 da Convenção contrariava o inciso LXVII do art. $5^{\circ}$ da novel Constituição brasileira. Assim, desde 1992, o ordenamento brasileiro convive com duas normas distintas acerca da previsão de prisões por dívidas: a) o art. 7.7 da Convenção Americana, que permite apenas a prisão por dívida no caso de inadimplemento de obrigação alimentar; e b) o art. $5^{\circ}$, LXVII, da Constituição Federal, que, além do caso de "inadimplemento voluntário e inescusável de obrigação alimentícia”, estende a previsão da prisão por dívida ao “depositário infiel”.

Diante da ausência de dispositivos constitucionais nítidos acerca das relações entre normas de direito interno e internacional e da histórica pouca (para não dizer quase nenhuma) atenção das Universidades brasileiras ao estudo do direito internacional, ${ }^{130}$ os Tribunais brasileiros posicionaram-se de forma majoritária, até 2008, no sentido de que o art. 7.7 da Convenção Americana, perdia sua eficácia no plano interno ao deparar-se com o art. $5^{\circ}$, LXVII, da Constituição Federal. ${ }^{131}$ Tal percepção, entretanto, sofreu radical mudança em 03/12/2008 com o histórico julgamento do RE n. 466.343/SP, em que o STF reconheceu por cinco votos a quatro que "os tratados internacionais de direitos humanos subscritos pelo Brasil possuem status normativo supralegal, o que torna inaplicável a legislação infraconstitucional com ele conflitantes, seja ela anterior ou posterior ao ato de ratificação e que, desde a ratificação, pelo Brasil, sem qualquer reserva, do Pacto Internacional dos Direitos Civis e Políticos (art. 11) e da Convenção Americana sobre Direitos Humanos - Pacto de San José da Costa Rica (art. 7.7), não há mais base legal para a prisão civil do depositário infiel”. ${ }^{13}$ Pouco mais de um ano depois, a Súmula Vinculante n. 25, de 16 de dezembro de 2009, aboliu de vez a figura da prisão civil do depositário infiel no Brasil.

No entanto, os desdobramentos da sentença de 24 de novembro de 2010 (Série C, n. 219, da Corte Interamericana) relativa ao Caso Gomes Lund e outros ("Guerrilha do Araguaia”), têm revelado que os dispositivos da Convenção Americana relativos à eficácia das sentenças da Corte no plano interno ainda carecem de maior compreensão 
no Brasil. No caso Gomes Lund, a Corte Interamericana declarou que a vigência e a eficácia da Lei n. 6.683/79, voltada à anistia de agentes do Estado brasileiro que cometeram crimes contra a humanidade como mortes, torturas e desaparecimentos durante o período da ditadura militar de 1964 a 1985, são totalmente incompatíveis com a Convenção Americana. ${ }^{133}$

Ocorre que, poucos dias após a sentença do Caso Lund Gomes, autoridades dos Poderes Executivo e Judiciário brasileiro em declarações à imprensa resistiam à decisão da Corte. O Presidente do STF, Min. Cezar Peluso, que na Extradição n. 1.085 de Cesare Battisti tinha se manifestado no sentido de não ter nexo nem senso conceber que sejam celebrados tratados para depois não serem cumpridos, ${ }^{134}$ declarou: “A eficácia (da decisão da CIDH) se dá no campo da convencionalidade. Não revoga, não anula e não cassa a decisão do Supremo"; e complementando sua convicção sobre a ineficácia da determinação da Corte Interamericana em revogar a Lei de Anistia aos agentes de Estado autores de crimes contra a humanidade, o mesmo Ministro desafiou: "Se alguém for processado e condenado por esses crimes poderá imediatamente pedir habeas corpus no STF. O Supremo vai conceder na hora”. 135

Esquecendo-se de que dois anos antes o STF, por meio do RE n. 466.343/SP e da Súmula Vinculante n. 25, garantiu a eficácia no plano interno das normas da Convenção Americana, e por consequência do reconhecimento do Brasil à competência contenciosa da Corte Interamericana, outros Ministros do STF também fizeram declarações à imprensa no sentido de que as decisões da Corte careciam de efeitos jurídicos no plano interno. ${ }^{136}$ O Ministro da Defesa, e ex-Ministro do STF, Nelson Jobim, definiu a sentença da Corte como "completamente anódina". 137

Em suma, de acordo com o RE n. 466.343/SP e a Súmula Vinculante n. 25 do STF, conclui-se que os dispositivos da Convenção Americana têm eficácia privilegiada no Brasil, em especial no que diz respeito ao cumprimento do art. $7^{\circ}$ e à proibição da prisão por dívida. No entanto, em relação ao cumprimento das sentenças da Corte, segundo as declarações à imprensa feitas por alguns Ministros do STF, o Brasil não é obrigado a cumprir o art. 68.1 da Convenção Americana, que garante eficácia imediata às sentenças da Corte Interamericana. Tais conflitantes posicionamentos não tardaram a ser rebatidos. O Ministro do STF Carlos Ayres Britto, por exemplo, contrapôs seus colegas ao resumir tal episódio como "uma saia justa, um constrangimento para o País, criado pelo poder que é o menos sujeito a esse tipo de vulnerabilidade (o Judiciário)". 138

Vale destacar que a eficácia das decisões da Corte Interamericana no plano interno nem sequer dependem da observância dos trâmites de homologação de sentença "proferida por tribunal estrangeiro". Ora, como a própria lei diz, os procedimentos de homologação são aplicados apenas a sentenças de tribunal estrangeiro, ou seja, "proferidas por um tribunal afeto à soberania de determinado Estado”. ${ }^{139}$ Assim, não se pode confundir o direito internacional com o estrangeiro: "as sentenças internacionais, 
proferidas por tribunais internacionais [...] não se vinculam à soberania de nenhum Estado, tendo, pelo contrário, jurisdição sobre o próprio Estado”. ${ }^{140}$

Os questionamentos em torno da eficácia das sentenças da Corte Interamericana no plano interno poderiam se extinguir se o Brasil tivesse alguma regulação interna tornando mais célere o cumprimento de decisões provenientes da Corte Interamericana. ${ }^{141}$ Flávia Piovesan, no entanto, destaca que existem medidas internas para execução das sentenças internacionais no Brasil, uma vez que estas constituem títulos judiciais e o art. 109, III, da Constituição garante que aos juízes federais cabe "processar e julgar as causas fundadas em tratado [...] da União com Estado estrangeiro ou organismo internacional”. Segundo Flávia Piovesan, o descumprimento sponte sua de uma decisão da Corte Interamericana assegura à vítima o direito e ao Ministério Público Federal o dever institucional de deflagrar ação judicial visando ao cumprimento da sentença. ${ }^{142}$

A busca da celeridade no cumprimento da sentença no plano interno pode também ser feita por intermédio de maior atuação da OEA. O art. 65 da Convenção Americana determina à Corte que casos de não cumprimento de suas sentenças sejam relatados à Assembleia Geral da OEA para que a Organização tome as medidas necessárias para que as decisões da Corte sejam cumpridas. No entanto, na prática, a Assembleia Geral da OEA não tem se esforçado na adoção de sanções em prol do cumprimento das decisões da Corte. ${ }^{143}$ Tal postura, na realidade, fragiliza não só a Corte Interamericana, mas a própria OEA. Como exemplo, o governo brasileiro, em 2011, ao deparar-se com um pedido de medida cautelar pleiteando a suspensão das obras da usina de Belo Monte, optou por destratar publicamente a Comissão Interamericana e suspender repasses de verba à OEA. Trata-se de ilustrativo episódio do quanto à compreensão dos elementos do direito pós-moderno se encontra no Brasil em estágio aquém da maturidade. ${ }^{144}$

Nesse sentido, torna-se cada vez mais necessário que o estudo dos posicionamentos da Comissão e Corte Interamericanas sobre a temática ambiental e suas interconexões com a garantia dos direitos fundamentais seja compreendido como uma contribuição do sistema interamericano ao desafio de aperfeiçoar a proteção ao meio ambiente e aos direitos fundamentais nas Américas e em especial, no Brasil.

\section{CONCLUSÕES}

A proteção ambiental no âmbito internacional, garantida pelos princípios da Declaração sobre o Ambiente Humano de Estocolmo 1972 e da Declaração sobre Meio Ambiente e Desenvolvimento do Rio de Janeiro 1992, é estruturada por um sistema de conferências que se por um lado permite a aceleração da entrada em vigor de suas decisões por meio da adoção de normas de soft law, por outro não tem o poder de aplicar sanções a Estados descumpridores de tais normas. Vista a questão sob outro ângulo, porém as Declarações de Estocolmo e Rio de Janeiro permitem 
inter-relações entre questões ambientais e temas de direitos humanos, que já se inserem em sistemas jurídicos de proteção mais desenvolvidos.

Assim, a percepção de que o acesso a um meio ambiente "sadio", "equilibrado" e "decente" constitui forma de proteção de direitos civis e políticos - como o direito à informação, participação política e desenvolvimento de medidas jurídicas protetivas -, ou ainda de garantia de direitos econômicos, sociais e culturais - como os direitos ao desenvolvimento e acesso à saúde -, tem feito com que os temas de cunho ambiental possam ser incorporados a casos relativos à proteção de direitos humanos de primeira dimensão.

Por isso, a inserção de temas ambientais no sistema interamericano só se faz possível mediante a vinculação destes a dispositivos da Declaração Americana de Direitos e Deveres do Homem ou da Convenção Americana sobre Direitos Humanos. A rigorosa observância dos dispositivos da Convenção para que uma questão ambiental seja inserida à sistemática da Comissão e Corte Interamericanas constitui, sim, um ônus à proteção internacional do meio ambiente. Mesmo assim, vale realçar que dentro da atual estrutura normativa internacional, marcada pela fragilidade ou "eficácia relativa" de normas que protejam o ambiente por si só, a técnica da proteção ambiental pela via reflexa ou indireta mostra-se uma importante via de amadurecimento e aperfeiçoamento dos mecanismos voltados não só à defesa do meio ambiente, mas também dos direitos humanos.

No entanto, o sistema interamericano não pode ser visto como tábua de salvação à proteção ambiental e aos direitos humanos, em substituição à atuação dos Estados-partes da OEA. Pelo contrário, sua atuação é complementar a dos Estados, que possuem, estes sim, a primazia na defesa dos direitos humanos. Portanto, o objetivo do sistema interamericano é induzir ou incentivar um comportamento no plano interno compatível com o fim comum da comunidade internacional e dos Estados: o aperfeiçoamento das políticas voltadas à garantia dos direitos fundamentais. No Brasil, tais objetivos - ainda que de forma incipiente - têm sido alcançados à medida que posicionamentos da Comissão e Corte Interamericanas relativos ao aperfeiçoamento da proteção aos direitos humanos e ao meio ambiente têm sido aplicados no âmbito interno. É o que se constata quando, por exemplo, o Supremo Tribunal Federal passa a defender a eficácia no plano interno da Convenção Americana sobre Direitos Humanos.

Ocorre que, seja pela tímida dedicação das universidades brasileiras ao estudo da Convenção Americana, seja pelo contraditório comportamento de ministros do STF que ora reconhecem a necessidade da eficácia dos tratados de direitos humanos, ora se negam a cumprir decisões da Corte Interamericana, a percepção das contribuições do sistema interamericano não parece ter alcançado um grau de maturidade suficiente em nosso país. Nesse sentido, o estudo dos posicionamentos da Comissão e Corte Interamericanas sobre a temática ambiental e suas interconexões com a garantia dos 
direitos fundamentais possibilita não só a melhor compreensão do fenômeno da inserção do meio ambiente no sistema interamericano, mas principalmente sinaliza que as técnicas interpretativas da Comissão e Corte contribuem com o aperfeiçoamento da proteção ao meio ambiente e aos direitos humanos no âmbito interno dos Estados, em especial, no Brasil, país que seja por seu grandioso espaço territorial, seja por suas potencialidades político-econômicas, constitui-se no maior Estado-parte da Convenção Americana sobre Direitos Humanos.

: ARTIGO APROVADO (15/05/2013) : RECEBIDO EM 22/03/2012

\section{NOTAS}

1 SANDS, Philippe (Ed.). Greening international law. London: Earthscan Publications Limited, 1993; e TEIXEIRA, Gustavo de Faria Moreira. O greening no sistema interamericano de direitos humanos. Curitiba: Juruá, 2011.

2 Cf. SOARES, Guido. Direito internacional do meio ambiente: emergências, obrigações e responsabilidades. São Paulo: Atlas: 2001, p. 45-55.

3 KISS, Alexandre; SHELTON, Dinah. Judicial handbook on environmental Law. Nairobi: United Nations Environment Programme, 2005, p. 20.

4 KISS, Alexandre; SHELTON, Dinah. Guide to international environmental law. Koninlijke Brill, NV, Leiden: Martinus Nijhoff Publishers, 2007, p. 89-109. Sobre princípios do direito internacional do meio ambiente, v. também SANDS, Phillipe. Principles of international environmental law. Manchester: Manchester University Press, 1995.

5 SOARES, Guido Fernando Silva. A proteção internacional do meio ambiente. Barueri: Manole, 2003, p. 48-73.

6 Para detalhes, v. MAZZUOLI, Valerio de Oliveira. Direito dos tratados. São Paulo: RT, 2011, p. 85-146.

7 No Brasil, nos moldes do art. 84, VIII, da Constituição Federal, a assinatura das negociações de tratado internacional é competência privativa do Presidente da República, podendo haver delegação a plenipotenciários seus, como o Ministro das Relações Exteriores e os chefes de missão diplomática etc.

8 No Brasil, a aprovação de um tratado é feita por referendo congressual, competindo, nos termos do art. 49, I, da Constituição Federal, ao Congresso Nacional "resolver definitivamente sobre tratados, acordos ou atos internacionais que acarretem encargos ou compromissos gravosos ao patrimônio nacional”.

9 SOARES, Guido Fernando Silva. Dez anos após Rio-92: o cenário internacional, ao tempo da cúpula mundial sobre desenvolvimento sustentável (Johanesburgo, 2002) In: MAZZUOLI, Valerio de Oliveira; IRIGARAY, Carlos Teodoro Hugueney (Orgs.). Novas perspectivas do direito ambiental brasileiro: visões interdisciplinares. Cuiabá: Cathedral, 2009, p. 12.

10 SOARES, Guido Fernando Silva. Dez anos após Rio-92..., cit., p. 13.

11 MAZZUOLI, Valerio de Oliveira. Curso de direito internacional público. 5. ed. São Paulo: RT, 2011, p. 986. 
12 Cf. CHINKIN, Christine M. The challenge of soft law: development and change in international law. The International and Comparative Law Quarterly, v. 38, n. 4, oct./1989, p. 850-866.

13 SOARES, Guido Fernando Silva. Dez anos após Rio-92..., cit., p. 12-14.

14 Acredita-se, contudo, que a Declaração Universal de 1948 certamente mencionaria o direito ao meio ambiente, se fosse negociada hoje. V. MAZZUOLI, Valerio de Oliveira. Direitos humanos e meio ambiente: um diálogo ente os sistemas internacionais de proteção. In: MAZZUOLI, Valerio de Oliveira; IRIGARAY, Carlos Teodoro Hugueney (Orgs.). Novas perspectivas do direito ambiental brasileiro: visões interdisciplinares, cit., p. 63.

15 CANÇADO TRINDADE, Antônio Augusto. Direitos humanos e meio ambiente: paralelo dos sistemas de proteção internacional. Porto Alegre: Sergio Antonio Fabris, 1993, p. 196.

16 MAZZUOLI, Valerio de Oliveira. Direitos humanos e meio ambiente: um diálogo ente os sistemas internacionais de proteção, cit., p. 61.V. também a pioneira ideia de "diálogo das fontes" em: JAYME, Erik. Identité culturelle et intégration: le droit international privé post-moderne. Recueil des Cours, v. 251, 1995, p. 259.

17 SOHN, Louis B. The new international law: protection of the rights of the individuals rather than the states. American University Law Review, v. 32, n. 1, 1982, p. 17.

18 V. MELlo, Celso D. Albuquerque de. Curso de direito internacional público. 15. ed, rev. e atual. Rio de Janeiro: Renovar, 2004, v. II, p. 206-207; 1009-1010; e RAUBER, Jochen. The United Nations - a Kantian dream come true? Philosophical perspectives on the constitutional legitimacy of the World Organization. Hanse Law Review, The E-Journal on European, International and Comparative Law, v. 5, n. 1, 2009, p. 49-76.

19 Sobre a proteção aos direitos civis e políticos na Declaração Universal, v. BONAVIDES, Paulo. Do Estado liberal ao Estado social. 5. ed. Belo Horizonte: Del Rey, 1993, p. 27; SALDANHA, Nelson. O Estado moderno e a separação dos poderes. São Paulo: Saraiva, 1987, p. 38; e LAFER, Celso. Ensaios sobre a liberdade. São Paulo: Perspectiva, 1980 , p. $18-19$.

20 BOBBIO, Norberto; MATTEUCCI, Nicola; e PASQUINO, Gianfranco. Tradução Carmen Varriale et al. Dicionário de política. 5. ed. Brasília: Editora Universidade de Brasília: 2000, p. 357.

21 Sobre a classificação dos dispositivos da Declaração Universal e a proteção aos direitos econômicos, sociais e culturais, v. BONAVIDES, Paulo. Curso de direito constitucional. 10. ed. São Paulo: Malheiros, 2000, p. 474-482; CASESSE, Antônio. Human rights in a changing world. Philadelphia: Temple University Press, 1990, p. 38-39; CLAUDE, Richard Pierre; WESTON, Burns H. (Orgs.). Human rights in the world community: issues and action. Philadelphia: University of Pennsylvania Press, 1989, p. 16-17; GROSS ESPIELL, Héctor. Estudios sobre derechos humanos. Madrid: Civitas, 1988, p. 328-332; HENKIN, Louis. International law: politics, values and functions. Boston: Martinus Nijhoff, 1990, p. 234-239; LAMBERT, Jean-Marie. Curso de direito internacional público: o mundo global. 5. ed. Goiânia: Kelps, 2004, p. 127-128; LINDGREN ALVES, José Augusto. O sistema internacional de proteção dos direitos e o Brasil. Arquivos do Ministério da Justiça. Brasília v. 46, n. 182 (jul./dez. 1993), p. 89; e VASAK, Karel. The international dimensions of human rights. Tradução e revisão Phillip Aston. Connecticut: Greenwood Press, 1982, p. 29-30.

22 Sobre o sistema de monitoramento dos Pactos de Nova York, v. BUERGUENTHAL, Thomas. International human rights. Minnesota: West Publishing, 1988, p. 42-44; HENKIN, Louis. International law: politics, values and functions, cit., p. 234-239; LINDGREN ALVES, José Augusto. O sistema internacional de proteção dos direitos e o Brasil, cit., p. 94; MERON, Theodor (Org.). Human rights in international law: legal and policy issues. Oxford: Clarendon Press, 1984, p. 84, 161; MAZZUOLI, Valerio de Oliveira. Curso de direito internacional público, cit., p. 629; MAZZUOLI, Valerio de Oliveira. Direitos humanos, constituição e os tratados internacionais: estudo analítico da situação e aplicação do tratado na ordem jurídica brasileira. São Paulo: Editora Juarez de Oliveira, 2002, p. 324; PIOVESAN, Flávia. Direitos humanos e o direito constitucional internacional. 7. ed. São Paulo: Saraiva, 2006, p. 154-177; STEINER, Henry. The youth of rights review of Henkin: the age of rights. Harvard Law Review, v. 104, n. 4, 1991, p. 927; STEINER, Henry; ALSTON, Philip. International human rights in context - law, politics and morals. 2. ed. Oxford: Oxford University Press, 2000, p. 257-314; p. 710; e STIGLITZ, Joseph E. Globalization and its discontents. New York-London: WW Norton Company, 2003. 
23 Sobre a Conferência de Viena, v. LINDGREN ALVES, José Augusto. O significado político da Conferência de Viena sobre direitos humanos. Revista dos Tribunais, n. 713, março 1995, p. 284-288; SOUSA SANTOS, Boaventura de. Uma concepção multicultural de direitos humanos. Revista Lua Nova, São Paulo, v. 39, 1997, p. 105-201; e HUMAN RIGHTS WATCH. World Report 1994: Events of 1993, New York, Human Rights Watch, 1994, p. 17.

24 CANÇADO TRINDADE, Antônio Augusto. A proteção internacional dos direitos humanos no limiar do novo século e as perspectivas brasileiras. Temas de política externa brasileira II. 1994, v. 1, p. 173.

25 MAZZUOLI, Valerio de Oliveira. Curso de direito internacional público, cit., p. 808-812; e p. 946-963.

26 SILVA, Geraldo Eulálio do Nascimento; ACCIOLY, Hildebrando. Manual de direito internacional público. 15. ed. São Paulo: Saraiva, 2002, p. 366. Cf., ainda: ALSTON, Philip. Conjuring up new human rights: a proposal for quality control. American Journal of International Law. v. 78, 1984, p. 607-621; BOYLE, Alan. The role of international human rights law in the protection of the environment. In: ANDERSON, Michael R; BOYLE, Alan E. (Orgs.). Human rights approaches to environmental protection. Oxford: Oxford University Press, 1996, p. 43-70; CANÇADO TRINDADE, Antônio Augusto. Os direitos humanos e o meio ambiente, cit., p. 162-164; e KISS, Alexandre; SHELTON, Dinah. Guide to international environmental law, cit., p. 237.

27 PIOVESAN, Flávia. Direitos humanos: desafios e perspectivas contemporâneas. Revista do Instituto de Direito Constitucional e Cidadania. Londrina, ano I, v. 1, abr. 2005, p. 56. Cf. ainda: CANÇADO TRINDADE, Antônio Augusto. Direitos humanos e meio ambiente, cit., p. 195; LINDGREN ALVES, José Augusto. O significado político da Conferência de Viena sobre direitos humanos, cit., p. 284-288.

28 V. MAZZUOLI, Valerio de Oliveira. Curso de direito internacional público, cit., p. 992; SHELTON, Dinah. Human rights, environmental rights and the right to the environment. Stanford Journal of International Law. v. 28, Palo Alto: Stanford University, 1991, p. 103-138.

29 V. KISS, Alexandre; SHELTON, Dinah. Guide to international environmental Law, cit., p. 238; e SILVA, José Afonso da. Direito ambiental constitucional. 3. ed. São Paulo: Malheiros, 2000, p. 67.

30 CANOTILHO, Joaquim José Gomes. Direito constitucional ambiental português e da União Europeia. In: CANOTILHO, Joaquim José; LEITE, José Rubens Morato (Orgs.). Direito constitucional ambiental brasileiro. 2. ed. São Paulo: Saraiva, 2008, p. 5.

31 V. KISS, Alexandre. Os direitos e interesses das gerações futuras e o princípio da precaução. In: VARELLA, Marcelo Dias \& PLATiaU, Ana Flávia Barros (Orgs.). Princípio da precaução. Belo Horizonte: Del Rey, 2004, p. 1-12.

32 V. CANÇADO TRINDADE, Antônio Augusto. Os direitos humanos e o meio ambiente. In: SYMONIDES, Janusz (Org.). Direitos humanos: novas dimensões e desafios. Brasília: UNESCO Brasil, Secretaria Especial dos Direitos Humanos, 2003, p. 166-167.

33 CANÇADO TRINDADE, Antônio Augusto. Os direitos humanos e o meio ambiente. In: SYMONIDES, Janusz (Org.). Direitos humanos, cit.,, p. 168.

34 Por intermédio de instrumentos como os princípios das Declarações de Estocolmo sobre o Meio Ambiente Humano de 1972 e do Rio de Janeiro sobre Meio Ambiente e Desenvolvimento de 1992; o preâmbulo e os Princípios n. 6 e 23 da Carta Mundial da Natureza de 1982; e os Princípios n. 1 e 20 do Relatório da Comissão Mundial sobre Meio Ambiente e Desenvolvimento de 1987.

35 CANÇADO TRINDADE, Antônio Augusto. Direitos humanos e o meio ambiente, cit., p. 170. V. também: WORLD COMMISSION ON ENVIRONMENT AND DEVELOPMENT. Our common Future. Oxford: Oxford University Press, 1987, p. 261-289.

36 CANÇADO TRINDADE, Antônio Augusto. Direitos humanos e o meio ambiente, cit., p. 179-180.

37 Cf. CANÇADO TRINDADE, Antônio Augusto. Os direitos humanos e o meio ambiente, cit., p. 173-180. CHURCHILL, Robin. Environmental Rights in Existing Human Rights Treaties. In: ANDERSON, Michael R; BOYLE, 
Alan E. (Orgs.). Human rights approaches to environmental protection. Oxford: Oxford University Press, 1996, p. 89-108; e MAZZUOLI, Valerio de Oliveira. Curso de direito internacional público, cit., p. 734-745.

38 Cf. CANÇADO TRINDADE, Antônio Augusto. Os direitos humanos e meio ambiente, cit., p. 187; KISS, Alexandre; SHELTON, Dinah. Guide to international environmental Law, cit., p. 239; MAZZUOLI, Valerio de Oliveira. Direitos humanos e meio ambiente: um diálogo ente os sistemas internacionais de proteção, cit., p. 63; MITCHELL, Ronald B. Problem structure, institutional design, and the relative effectiveness of international environmental agreements. Global Environmental Politics, v. 6, n. 3, ago. 2006, p. 72-89; e Relatório da OEA, AG/Res. 1819 (XXXI-0/01), Direito humanos e meio ambiente, de 4 de abril de 2002.

39 GOMES, Carla Amado. Textos dispersos de direito do ambiente. Lisboa: Associação Acadêmica da Faculdade de Direito, 2010, v. III, p. 167.

40 V. KISS, Alexandre; SHELTON, Dinah. Judicial handbook on environmental law, cit., p. 30-31. Cf. ainda: BOYLE, Alan. Human rights and the environment: a reassessment. UNEP Human Rights and Environment. UNEP, 2010.

41 CANÇADO TRINDADE, Antônio Augusto. Os direitos humanos e o meio ambiente, cit., p. 187.

42 BOYLE, Alan. Human rights and the environment: a reassessment, cit., p. 1-2.

43 CANÇADO TRINDADE, Antônio Augusto. Os direitos humanos e o meio ambiente, cit., p. 187-188.

44 CANÇADO TRINDADE, Antônio Augusto. Os direitos humanos e o meio ambiente, cit., p. 187-188; e ENGLE, Eric. Third party effect of fundamental rights (Drittwirkung). Hanse Law Review, v. 5, n. 2, 2009, p. 165-173.

45 CANÇADO TRINDADE, Antônio Augusto. Os direitos humanos e o meio ambiente, cit., p. 184; 188; e CANÇADO TRINDADE, Antônio Augusto. Direitos Humanos e meio ambiente: paralelo dos sistemas de proteção internacional. Porto Alegre: Sérgio Antônio Fabris Editora, 1993, p. 89-112.

46 GOMES, Carla Amado. Textos dispersos de direito do ambiente, cit., p. 172-173; MAZZUOLI, Valerio de Oliveira. Curso de direito internacional público, cit., p. 908-909; e CANÇADO TRINDADE, Tratado de direito internacional dos direitos humanos, v. III, cit., p. 40.

47 Corte Europeia, Caso Powell and Rayner v. Reino Unido. Acórdão de 21 de fevereiro de 1990, proc. 9310/81.

48 Expressão de Philippe Sands, in Greening international law, London: Earthscan Publications Limited, 1993.

49 Corte Europeia, Caso Powel and Rayner v. o Reino Unido, cit., pars. 40-42.

50 Corte Europeia, Caso Hatton e outros v. Reino Unido. Acórdão de 2 de outubro de 2001, proc. 36022/97.

51 Corte Europeia, Caso López Ostra v. Espanha. Acórdão de 9 de dezembro de 1994, proc. 16798/90; Caso Ana Maria Guerra e outros v. Itália. Acórdão de 19 de fevereiro de 1998, procs. 116/1996/735/932; Corte Europeia, Caso Moreno Gómez v. Espanha. Acórdão de 16 de novembro de 2004, proc. 4143/02; Caso Giacomelli v. Itália. Acórdão de 2 de novembro de 2006, proc. 59909/00; Caso Fadeïeva v. Rússia. Acórdão de 9 de junho de 2005, proc. 55723/00; Caso Öneryildiz v. Turquia. Acórdão de 18 de junho de 2002, proc. 48939/99; Corte Europeia, Caso Taskin e outros v. Turquia. Acórdão de 10 de novembro de 2004, proc. 46117/99; Caso Tatar v. Romênia. Acórdão de 27 de janeiro de 2009 , proc. $67021 / 01$.

52 GOMES, Carla Amado. Textos dispersos de direito do ambiente, cit., p. 163-205.

53 Sobre o avanço do poder econômico nas áreas dos povos indígenas e tradicionais, v. GARFIELD, Seth. A nationalist environment: indians, nature and the construction of the Xingu National Park in Brazil. Luso-Brazilian Review, v. 41, n. 1, 2004, p. 139-167; SHIVA, Vandana. Biopirataria: a pilhagem do conhecimento. Tradução Laura Cardellini Barbosa de Oliveira. Petrópolis: Vozes, 2001, p. 23-29; e VARVARIGOS, Dimitrios. Environmental degradation, longevity and the dynamics of economic development. Environmental and Resource Economics, v. 46, issue 1, 2010, p. 59-73. 
54 Dos 34 membros ativos da OEA, somente Antígua e Barbuda, Bahamas, Belize, Canadá, Estados Unidos, Guiana, Saint Kitts e Nevis, Santa Lúcia e São Vicente e Granadina ainda não ratificaram a Convenção. Dos 24 Estados da OEA que já ratificaram a Convenção Americana, apenas dois - Trinidad e Tobago e Venezuela - denunciaram a Convenção. Por denúncia entende-se todo ato pelo qual o partícipe de um tratado internacional manifesta, de forma unilateral, sua vontade de deixar de ser parte do acordo anteriormente firmado; tal procedimento não enseja qualquer punição ao Estado denunciante, sendo regulado pela Convenção de Viena sobre o Direito dos Tratados de 1969. A denúncia da Convenção Americana é regulamentada pelo seu art. 78, sendo facultado aos seus Estados-partes denunciá-la, depois de expirado o prazo de cinco anos de entrada em vigor da mesma (18 de julho de 1978) e mediante aviso prévio de um ano ao Secretário Geral da OEA. Trinidad e Tobago notificou a denúncia ao Secretário Geral da OEA em 28.05.1998. A República Bolivariana da Venezuela manifestou sua denúncia em 10 de setembro de 2012. Ver: General Information of the American Convention on Human Rights disponível em: http://www.oas.org/juridico/english/Sigs/b-32.html (visited May 20, 2012); Ver também: GOMES, Luiz Flávio; MAZZUOLI, Valerio de Oliveira. Comentários à Convenção Americana sobre Direitos Humanos: Pacto de San José da Costa Rica. $3^{\text {a }}$ ed. rev., atual e ampl. São Paulo, Revista dos Tribunais, 2010, p. 360-363; e TEIXEIRA, Gustavo de Faria Moreira. O greening no sistema Interamericano de direitos humanos. Curitiba: Juruá, 2011. p. 78-81.

55 Dos 24 Estados-partes da Convenção, apenas três - Dominica, Grenada e Jamaica - ainda não se submetem à jurisdição da Corte. Disponível em: <http://www.oas.org/en/iachr/mandate/Basics/conventionrat.asp >. Acesso em: 26 fev. 2012. Cf. ainda: art. 62, Convenção Americana; e FIX-ZAMUDIO, Hector. Protección jurídica de los derechos humanos. México: Comisión Nacional de Derechos Humanos, 1991, p. 164.

56 V. art. $3^{\circ}$ do Estatuto Corte IDH; arts. 50 a 55 da Convenção Americana; e Opinião Consultiva OC-20/09 de 29 de setembro de 2009, Série A, n. 20 - Artigo 55 da Convenção Americana sobre Direitos Humanos, pars. 21; 86.

57 Sobre a inserção da temática ambiental no sistema interamericano de direitos humanos v. TEIXEIRA, Gustavo de Faria Moreira. O greening no sistema interamericano de direitos humanos, cit., p. 99-144.

58 V. CANÇADO TRINDADE, Antônio Augusto. Tratado de direito internacional dos direitos humanos. v. II. Porto Alegre: Sergio Fabris Editor, 1999, p. 499. V. Relatório sobre a situação das defensoras e defensores de direitos humanos nas Américas, OEA/Ser.L/V/II.124. Março 7, 2006. Sobre as condições dos povos indígenas nas Américas, v. Derecho de los pueblos indígenas y tribales sobre sus tierras ancestrales y recursos naturales: normas y jurisprudencia del Sistema Interamericano de Derechos Humanos. OEA/Ser.L/V/II, Doc.56/09, 30 de dezembro de 2009. Ver: http://cidh.org/countryrep/TierrasIndigenas2009/Indice.htm, último acesso em: 08 de julho de 2013.

59 Em cumprimento da AG/Res. 1819 (XXXI-O/01), adotada na terceira sessão plenária da OEA, realizada em 5 de junho de 2001. V. MAZZUOLI, Valerio de Oliveira. Curso de direito internacional público, cit., p. 1001.

60 Resolução n. 12/85, Caso n. 7615 (Brasil), 5 de março de 1985, constante do Relatório Anual da CIDH 1984-85, OEA/Ser.L/V/II.66, doc. 10 rev.1, 1 outubro, 1985, 24, 31 (Caso Yanomami).

61 Caso Comunidade Mayagna (Sumo) Awas Tingni v. Nicarágua. Sentença de 31 de agosto de 2001. Série C n. 79 .

62 GOMES, Carla Amado. Textos dispersos de direito do ambiente, cit., p. 163-205.

63 Resolução n. 12/85, Caso n. 7615 (Brasil), cit., resolução 1.

64 Sobre os casos de temática ambiental analisados pela Comissão Interamericana de Direitos Humanos, v. TEIXEIRA, Gustavo de Faria Moreira. O greening no sistema interamericano de direitos humanos, cit., p. 163-227. Cf. ainda: CIDH. Informe n. 30/04, Solução Amistosa Mercedes Julia Huentes Beroiza, 11 de março de 2004; CIDH. Informe n. 40/04, Caso Comunidades Indígenas Maya de Toledo v. Belize, 12 outubro de 2004; CIDH. Informe n. 62/04, Caso Povo Indígena Kichwa de Sarayacu e seus membros v. Equador, 13 de outubro de 2004; CIDH. Informe n. 69/04, Caso San Mateo Huanchor v. Peru, OEA/Ser.L/V/II.122, Doc. 5, rev. 1, outubro de 2004; CIDH. Informe n. 75/09, Caso Comunidades Indígenas Ngöbe e seus membros do Vale do Rio Changuinola v. Panamá, 5 de agosto de 2009; Resolução de Medidas Cautelares Comunidades Indígenas Ngöbe e outros, MC-56-08, 17 de junho de 2009; Petition 1.413/05. Petition to the Inter American Commission on Human Rights. Violations resulting from global warming caused by the 
United States, December 7, 2005; e Medida Cautelar MC-382/10, Solicitação de Medidas Cautelares em favor das Comunidades tradicionais da bacia do Rio Xingu, Pará, Brasil, 11 de novembro de 2009.

65 Caso Comunidade Mayagna (Sumo) Awas Tingni v. Nicarágua. Sentença de 31 de agosto de 2001. Série C n. 79. Cf. ainda: TEIXEIRA, Gustavo de Faria Moreira. O greening no sistema interamericano de direitos humanos, cit., p. 232-243.

66 V. TEIXEIRA, Gustavo de Faria Moreira. O greening no sistema interamericano de direitos humanos, cit., p. $229-285$. Cf. ainda: Caso Moiwana v. Suriname. Sentença de 15 de junho de 2005. Série C, n. 124, par. 86; Caso Comunidade Indígena Yakye Axa v. Paraguai. Sentença 17 de junho de 2005. Série C, n. 125; Caso Comunidade Indígena Sawhoyamaxa v. Paraguai. Sentença de 29 de março de 2006. Série C, n. 146; Caso Povo Saramaka v. Suriname. Sentença de 28 de novembro de 2007. Série C, n. 172; e Resoluções de Medidas Provisórias do Caso Povo Saramaka. v. Suriname dos dias 6 de julho de 2004, 17 de junho de 2005 e 4 de fevereiro de 2010.

67 ANKERSEN, Thomas T; RUPPERT, Thomas K. Defending the polygon: the emerging human right to communal property. Oklahoma Law Review. v. 59, n. 4, Norman: University of Oklahoma College of Law , winter 2006, p. 684.

68 V. Art. 1.228, do Código Civil brasileiro.

69 MAGRAW, Daniel Barstow; BAKER, Lauren. Globalization and communities: community-based property rights and prior informed consent. Denver Journal of International Law and Policy. v. 35, n. 3 e 4, 2008, p. 416-418. Cf. ainda: GARFIELD, Seth. A nationalist environment: indians, nature and the construction of the Xingu National Park in Brazil, cit., p. 146-147; MAYZOLER, Marcel; ROUDART, Laurence. História das agriculturas no mundo: do neolítico à crise contemporânea. Tradução Cláudia F. Fallhuh Balduino Ferreira. São Paulo: Editora Unesp; Brasília: NEAD, 2010, p. 245-250; SHIVA, Vandana. Biopirataria: a pilhagem do conhecimento, cit., p. 18-21; e SHELTON, Dinah. Environmental Rights and Brazil's Obligations in the Inter-American Human Rights System. George Washington International Law Review, v. 40, 2008, p. 756-768.

70 V. ASOCIACIÓN INTERAMERICANA PARA LA DEFENSA DEL AMBIENTE-AIDA. Guia de defesa ambiental: construindo a estratégia para o litígio de casos diante do sistema interamericano de direitos humano, cit., p. 67; 86; 88; 90; MAGRAW, Daniel Barstow; BAKER, Lauren. Globalization and communities: community-based property rights and prior informed consent, cit., p. 427; e LEITE, José Rubens Morato; AYALA, Patryck de Araújo. Dano ambiental: do individual ao coletivo extrapatrimonial. 3. ed. São Paulo: RT, 2010, p. 260-308. Cf. ainda: TEIXEIRA, Gustavo de Faria Moreira. O greening no sistema interamericano de direitos humanos, cit., p. 243-251.

71 ANKERSEN, Thomas T; RUPPERT, Thomas K. Defending the polygon: the emerging human right to communal property, cit., p. 726-732; ASOCIACIÓN INTERAMERICANA PARA LA DEFENSA DEL AMBIENTE-AIDA. Guia de defesa ambiental: construindo a estratégia para o litígio de casos diante do sistema interamericano de direitos humano, cit., p. 39; 53;60-64; 77; 81; 85-89;91-94; 97; 114; 147.

72 ASOCIACIÓN INTERAMERICANA PARA LA DEFENSA DEL AMBIENTE-AIDA. Guia de defesa ambiental: construindo a estratégia para o litígio de casos diante do sistema interamericano de direitos humano, cit., p. 60-64; 88-89; 147; SHELTON, Dinah. Environmental rights and Brazil's obligations in the Inter-american Human Rights System, cit., p. 764. Cf. ainda: TEIXEIRA, Gustavo de Faria Moreira. O greening no sistema interamericano de direitos humanos, cit., p. 259-269.

73 ASOCIACIÓN INTERAMERICANA PARA LA DEFENSA DEL AMBIENTE-AIDA. Guia de defesa ambiental: construindo a estratégia para o litígio de casos diante do sistema interamericano de direitos humano, cit., p. 40; 60; 63-64; 67; 136; 147; SHELTON, Dinah. Environmental Rights and Brazil's Obligations in the Inter-American Human Rights System, cit., p. 764-768; 770; Cf. ainda: TEIXEIRA, Gustavo de Faria Moreira. O greening no sistema interamericano de direitos humanos, cit., p. 275-285.

74 CIDH. Informe n. 84/03, Parque Natural Metropolitano do Panamá, 22 de outubro de 2003. Cf. ainda: TEIXEIRA, Gustavo de Faria Moreira. O greening no sistema interamericano de direitos humanos, cit., p. 172-174.

75 SPILLER, Paula. The La Oroya case: the relationship between environmental degradation and human rights violation. Human rights brief. v. 18, issue 1, Washington D.C: American University of Washington College of Law, fall 
2010, p. 19; e 22. Cf. ainda: TEIXEIRA, Gustavo de Faria Moreira. O greening no sistema interamericano de direitos humanos, cit., p. 206-214.

76 Caso Claude Reyes y otros v. Chile. Sentença de 19 de setembro de 2006. Série C n. 151. Cf. ainda: TEIXEIRA, Gustavo de Faria Moreira. O greening no sistema interamericano de direitos humanos, cit., p. 269-275.

77 Assim chamado por Carla Amado Gomes.

78 Por todos, v. GOMES, Carla Amado. Textos dispersos de direito do ambiente, cit., p. 163-205.

79 GOMES, Carla Amado. Textos dispersos de direito do ambiente, cit., p. 167.

80 V. BOYLE, Alan. Human rights and the environment: a reassessment, p. 13-29; e SANDS, Philippe. Greening International Law. London: Earthscan Publications Limited, 1993.

81 Entre outros elementos estratégicos a serem verificados, destacamos as análises a) das condições políticas e sociais em torno de um caso; b) de instâncias alternativas; c) de recursos de jurisdição interna; e d) da determinação da responsabilidade do Estado. Para detalhes, v. TEIXEIRA, Gustavo de Faria Moreira. O greening no sistema interamericano de direitos humanos, cit., p. 141-158. Cf. ainda: BOYLE, Alan. Human rights and the environment: a reassessment, p. 13-29; e SANDS, Philippe. Greening International Law. London: Earthscan Publications Limited, 1993.

82 V. arts. 44 e 45 da Convenção Americana; e art. 25 do Regulamento da Comissão Interamericana. BOYLE, Alan. Human rights and the environment: a reassessment, cit., p. 13-29; e SANDS, Philippe. Greening International Law. London: Earthscan Publications Limited, 1993.

83 Argentina, Chile, Colômbia, Costa Rica, Equador, Jamaica, Nicarágua, Peru, Uruguai e Venezuela reconhecem a competência da Comissão Interamericana de receber e examinar comunicações interestatais. Disponível em: <http://www.oas.org/en/iachr/mandate/Basics/conventionrat.asp>. Acesso em: 26 fev. 2012. Cf. também: art. 35.1 da Convenção.

84 V. ASOCIACIÓN INTERAMERICANA PARA LA DEFENSA DEL AMBIENTE-AIDA. Guia de defesa ambiental: construindo a estratégia para o litígio de casos diante do sistema interamericano de direitos humanos. Bogotá: Editorial Gente Nueva, 2010, p. 23; CANÇADO TRINDADE, Antônio Augusto. Desafios e conquistas do direito internacional dos direitos humanos no início do século XXI. In: CACHAPUZ DE MEDEIROS, Antônio Paulo (Org.). Desafios do direito internacional contemporâneo. Brasília: Fundação Alexandre Gusmão, 2007, p. 277; art. 34 da Convenção Europeia para a Proteção dos Direitos Humanos e das Liberdades Fundamentais, Regra 36 do Regulamento do Tribunal Europeu de Direitos Humanos; artigos 1.2, 44.2, 46 e 46.1, d, da Convenção; arts. 24 e 28 do Regulamento da Comissão Interamericana; e CIDH. Informe n. 84/03, Parque Natural Metropolitano do Panamá, 22 de outubro de 2003, p. 33-37.

85 Art. 46.1, bec c, da Convenção.

86 LEDESMA, Hector Faúndez. El sistema interamericano de protección de los derechos humanos, aspectos institucionales y procesales. 3. ed. San José: IIDH, 2004, p. 293. Cf. ainda: CANÇADO TRINDADE. El agotamiento de los recursos internos en el sistema interamericano de protección de los derechos humanos. San José da Costa Rica/Brasília: Instituto Interamericano de Direitos Humanos, Comitê Internacional da Cruz Vermelha, Alto Comissariado das Nações Unidas para os Refugiados, Comissão da União Europeia, 1996.

87 CANÇADO TRINDADE, Antônio Augusto. Tratado de direito internacional dos direitos humano, cit., p. 39-40.

88 Relatório n. 40/04-Caso 12.053. Comunidades Indígenas Maias v. Belize. 12 de outubro de 2004, par.196. Cf. ainda: TEIXEIRA, Gustavo de Faria Moreira. O greening no sistema interamericano de direitos humanos, cit., p. 181-190.

89 V. TEIXEIRA, Gustavo de Faria Moreira. O greening no sistema interamericano de direitos humanos, cit., p. 84. Cf. também: ASOCIACIÓN INTERAMERICANA PARA LA DEFENSA DEL AMBIENTE-AIDA. Guia de defesa ambiental: construindo a estratégia para o litígio de casos diante do sistema interamericano de direitos humanos, cit., p. 27; art. 25, $\S 1$ a 3, do Regulamento da Comissão Interamericana. 
90 Art. 25.4, a, do Regulamento da Comissão. Cf. ainda GOMES, Luiz Flávio; MAZZUOLI, Valerio de Oliveira. Comentários à Convenção Americana sobre Direitos Humanos: Pacto de San José da Costa Rica. 3. ed. rev., atual e ampl. São Paulo: RT, 2010, p. 333-334.

91 Art. 25.5 do Regulamento da Comissão.

92 Convenção Americana, art. 63.2.

93 Ver: CANÇADO TRINDADE, Antônio Augusto. Tratado de direito internacional dos direitos humanos. Porto Alegre: Sergio Fabris Editor, 1999, v. II, p. 499; e MAZZUOLI, Valerio de Oliveira. Curso de direito internacional público, cit., p. 923-925.

94 A Comissão Interamericana solicitou a adoção de medidas cautelares em a) 24/04/2003; b) 17/12/2003; e c) 30/04/2004. A Corte Interamericana determinou a adoção de medidas provisórias em a) 06/07/2004; b) 17/06/2005; c) 18/12/2009; e d) 04/02/2010. V. TEIXEIRA, Gustavo de Faria Moreira. O greening no sistema interamericano de direitos humanos, cit., p. 190-197. Cf. ainda: Informe n. 62/04, Caso Povo Indígena Kichwa de Sarayacu e seus membros v. Equador, 13 de outubro de 2004; Medidas Provisórias. Caso povo indígena de Sarayacu. Resoluções de 6 de julho de 2004; 17 de junho de 2005; 18 de dezembro de 2009; e 4 de fevereiro de 2010.

95 Corte IDH. Caso Yakye Axa, par. 92. e CIDH, Relatório de Admissibilidade n. 62/04, Sarayacu, par. 49.

96 GOMES, Carla Amado. Textos dispersos de direito do ambiente, cit., p. 163-205; CANÇADO TRINDADE, Antônio Augusto. Os direitos humanos e o meio ambiente, cit., p. 184.

97 Informe n. 76/09, Caso Comunidade de La Oroya v. Peru; Caso Claude Reyes y otros v. Chile, cit., Série C n. 151; SPILLER, Paula. The La Oroya case: the relationship between environmental degradation and human rights violation. Human rights brief, cit., p. 19-23; TEIXEIRA, Gustavo de Faria Moreira. O greening no sistema interamericano de direitos humanos, cit., p. 206-214; e 269-275.

98 Cf. KNOX, John H. Linking human rights and climate change at the United Nations. Harvard Environmental Law Review. v. 33, Cambridge: Harvard Law School, 2009, p. 477-498; e WILSON, Sacoby M.; RICHARD, Roland; JOSEPH, Lesley; WILLIAMS, Edith. Climate change, environmental justice and vulnerability: an exploratory spatial analysis. Environmental Justice, v. 3, n. 1, 2010, p. 13-19.

99 Segundo os peticionários, as viagens, caçadas, pescarias, coleta de alimentos, construção de iglus e fixação de residência do povo Inuit têm sido inviabilizadas por fenômenos do aquecimento global como a fragilidade da espessura do gelo, encurtamento da temporada de neve, deslizamentos, erosões e enchentes imprevisíveis. O fato de os Estados Unidos ser o maior emissor de gases de efeito estufa e mesmo assim se recusar a implementar políticas de redução de emissões indica que o país é responsável pela degradação do ambiente do povo Inuit e por violações a dispositivos da Declaração Americana de Direitos e Deveres do Homem referentes ao direito à vida, à liberdade e à segurança (art. I), direito de residência e de ir e vir (art. VIII), de inviolabilidade do lar (art. IX), direito à saúde (art. XI) e aos benefícios da cultura (art. XIII) do povo Inuit do Círculo Polar Ártico. Cf. Petition 1.413/05, cit., p. 13-43; 92-103; e 112-114; OSOFSKY, Hari M. Inuit petition as a bridge? Beyond dialectics of climate change and indigenous people's rights. American Indian Law Review. v. 31, Norman: The University of Oklahoma College of Law, 2007, p. 675-698; e TEIXEIRA, Gustavo de Faria Moreira. O greening no sistema interamericano de direitos humanos, cit., p. 214-219.

100 Carta de Ariel E. Dulitzky, Secretário Executivo Adjunto da Comissão Interamericana para Paul Crowljey, representante legal de Sheila Watt-Cloutier el all na Petição 1.413/05, 16 de novembro de 2005. Cf. ainda: OSOFSKY, Hari M. Inuit petition as a bridge? Beyon dialectics of climate change and indigenous people's rights, cit., p. 675; e KNOX, John H. Linking human rights and climate change at the United Nations, cit., p. 482.

101 V. JAYME, Erik. Identité culturelle et intégration..., cit., p. 9-267.

102 Cf. PLACENCIA, Luis González. Deconstructing human rights: a standpoint from the postmodern understanding of justice. Revista do Instituto Brasileiro de Direitos Humanos. Ano 3, v. 3, n. 3, 2002, p. 152-162; DONNELLY, Jack. Universal human rights in theory and practice. 2. ed. Ithaca, New York: Cornell University Press, 
2003, p. 49-57; HENKIN, Louis. The age of rights. New York: Columbia University Press, 1990, p. 5; e VINCENT, R. J. Human rights and international relations. Cambridge: Cambridge University Press, 1986, p. 37-38.

103 FLORES, Joaquim Herrera. Direitos Humanos, interculturalidade e racionalidade de resistência, Sequência. Revista do Curso de Pós-Graduação em Direito da UFSC, v. 23, n. 44, 2002, p. 21.

104 "La civilisation postmoderne est caractérisée par un pluralisme de styles et de valeurs inconnu autrefois. L'âge de lumières avance l'idée et de tolérance envers lês autres, mais ce terme présupposait la conviction en la supériorité de sés propres valeurs. Aujourd'hui l'on a vu émerger [...] le droit à la différence. Son apparition est le signe d'une transformation radicale dans la perception de l'humanité." (JAYME, Erik. Identité culturelle et intégration..., cit., p. 251)

105 JAYME, Erik. Identité culturelle et intégration..., cit., p. 261.

106 Caso Moiwana v. Suriname, cit., par. 113. V. também: par. 87.

107 ASOCIACIÓN INTERAMERICANA PARA LA DEFENSA DEL AMBIENTE-AIDA. Guia de defesa ambiental: construindo a estratégia para o litígio de casos diante do sistema interamericano de direitos humano, cit., p. 67; 86; 88; 90; MAGRAW, Daniel Barstow; BAKER, Lauren. Globalization and communities: community-based property rights and prior informed consent, cit., p. 427.

108 MAZZUOLI, Valerio de Oliveira. Curso de direito internacional público, cit., p. 158

109 JAYME, Erik. Identité culturelle et intégration..., cit., p. 87.

110 JAYME, Erik. Identité culturelle et intégration..., cit., p. 259-261.

111 MAZZUOLI, Valerio de Oliveira. Tratados internacionais de direitos humanos e o direito interno. São Paulo: Saraiva, 2010, p. 129-177; e GOMES, Luiz Flávio; MAZZUOLI, Valerio de Oliveira. Comentários à Convenção Americana sobre Direitos Humanos, cit., p. 206-207.

112 Caso Comunidade Indígena Sawhoyamaxa v. Paraguai, cit., par. 140.

113 V. art. $1^{\circ}$ do Pacto Internacional sobre Direitos Civis e Políticos; e art. $1^{\circ}$ do Pacto Internacional dos Direitos Econômicos, Sociais e Culturais, 1966.

114 Caso Povo Saramaka. v. Suriname, cit., par. 93.

115 MAZZUOLI, Valerio de Oliveira. Curso de direito internacional público, cit., p. 90.

116 V. MAZZUOLI, Valerio de Oliveira. Monismo internacionalista dialógico. Revista Jurídica Consulex, Brasília, v. 14, n. 324, p. 50-51.

117 JAYME, Erik. Identité culturelle et intégration..., cit., p. 259.

118 V. AYALA CORAO, Carlos M. Recepción de la jurisprudencia internacional sobre derechos humanos por la jurisprudencia constitucional. Revista del Tribunal Constitucional, n. 6, Sucre, nov. 2004, p. 27.

119 GOMES, Luiz Flávio; MAZZUOLI, Valerio de Oliveira. Comentários à Convenção Americana sobre Direitos Humanos, cit., p. 209.

120 Sobre a prisão civil por dívida, v. MAZZUOLI, Valerio de Oliveira. Prisão civil por dívida e o Pacto de San José da Costa Rica. Rio de Janeiro: Forense, 2002.

121 GOMES, Luiz Flávio; MAZZUOLI, Valerio de Oliveira. Comentários à Convenção Americana sobre Direitos Humanos, cit., p. 54-79; MAZZUOLI, Valerio de Oliveira. O controle jurisdicional da convencionalidade das leis. São Paulo: RT, 2009, p. 64-135; MAZZUOLI, Valerio de Oliveira. Curso de direito internacional público, cit., p. 817-851. 
122 JAYME, Erik. Identité culturelle et intégration..., cit., p. 261.

123 V., por tudo, LEITE, José Rubens Morato; AYALA, Patryck de Araújo, Dano ambiental: do individual ao coletivo extrapatrimonial, cit., p. 287-289.

124 De Luiz Flávio Gomes e Valerio de Oliveira Mazzuoli (São Paulo: RT).

125 GOMES, Luiz Flávio; MAZZUOLI, Valerio de Oliveira. Comentários à Convenção Americana sobre Direitos Humanos: Pacto de San José da Costa Rica, cit., p. 8. Para um estudo da jurisprudência do sistema interamericano, ganha destaque a obra de: RAMOS, André de Carvalho. Direitos humanos em juízo: comentários aos casos contenciosos e consultivos da Corte Interamericana de Direitos Humanos. São Paulo: Max Limonad, 2001.

126 Cf. MAZZUOLI, Valerio de Oliveira. Curso de direito internacional público, cit., p. 813-847; MAZZUOLI, Valerio de Oliveira. Direitos Humanos, constituição e os tratados internacionais: estudo analítico da situação e aplicação do tratado na ordem jurídica brasileira, cit., p. 233-252; MAZZUOLI, Valerio de Oliveira. Prisão civil por dívida e o Pacto de San José da Costa Rica, p. 106-176; MAZZUOLI, Valerio de Oliveira. O controle jurisdicional da convencionalidade das leis, cit., p. 19-63; PIOVESAN, Flávia. Direitos humanos e o direito constitucional internacional, cit., p. 72-73; e LAFER, Celso. A internacionalização dos direitos humanos: constituição, racismo e relações internacionais. Barueri: Manole, 2005 , p. $16-18$.

127 MAZZUOLI, Valerio de Oliveira. Curso de direito internacional público, cit., p. 836; e MAZZUOLI, Valerio de Oliveira. O controle jurisdicional da convencionalidade das leis, cit., p. 64-135.

128 Sobre os tratados internacionais de direitos humanos nas Constituições dos Estados-partes da Convenção Americana, v. MAZZUOLI, Valerio de Oliveira. Curso de direito internacional público, cit., p. 847-851; BUERGUENTHAL, Thomas. El derecho internacional de los derechos humanos en las Constituciones latinoamericanas y en la Corte Interamericana de Derechos Humanos. Revista Latinoamericana de Derecho. año 1, n. 1, enero/junio, 2004, p. 141-180; FIX-ZAMUDIO, Hector. Protección jurídica de los derechos humanos. México: Comisión Nacional de Derechos Humanos, 1991, p. 173; CANÇADO TRINDADE, Antônio Augusto. Direito internacional e direito interno: suas interações na proteção dos direitos humanos. Instrumentos internacionais de proteção dos direitos humanos. São Paulo: Centro de Estudos da Procuradoria-Geral do Estado, 1996, p. 19; MANCHEGO, José F. Palomino; GARBONELL, José Carlos Remotti (Orgs.). Derechos humanos y constitución en Iberoamérica (Libro-homenaje a Germán J. Bidart Campos). Lima: Instituto Iberoamericano de Derecho Constitucional, 2002; BIDART CAMPOS, Bidart. Tratado de derecho constitucional argentino. Buenos Aires: Ediar, 1995, t. III, p. 277-278.

129 Aprovada pelo Decreto Legislativo n. 27, de 25 de setembro de 1992, e promulgada pelo Decreto n. 678, de 6 de novembro de 1992 .

130 Esta disciplina só voltou a ser matéria obrigatória nos cursos jurídicos no Brasil a partir de 1997, por ordem da Portaria do Ministério da Educação n. 1.886, de 30 de dezembro de 1994, que fixou as Diretrizes Curriculares do Curso de Direito.

131 "Incontáveis acórdãos do STJ reiteradamente negaram a validade para a prisão do depositário no caso da alienação fiduciária (REsp 7.943-RS; REsp 2.329-RS etc.). No STF, alguns antigos votos vencidos (dos Ministros Marco Aurélio, Francisco Rezek, Carlos Velloso, Sepúlveda Pertence etc.) não discrepavam do entendimento preponderante no STJ. Mas o pensamento majoritário no STF sempre foi no sentido de sua admissibilidade." (GOMES, Luiz Flávio; MAZZUOLI, Valerio de Oliveira. Comentários à Convenção Americana sobre Direitos Humanos: Pacto de San José da Costa Rica, cit., p. 74)

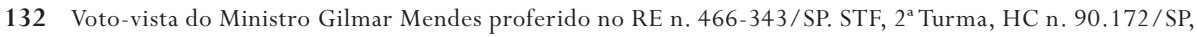
Rel. Min. Gilmar Mendes, j. 05/06/2007.

133 V. Corte IDH. Caso Gomes Lund e outros ("Guerrilha do Araguaia”) v. Brasil. Sentença de 24 de novembro de 2010, Série C, n. 219. Cf. ainda: RAMOS, André de Carvalho. Crimes da ditadura militar: a ADPF 153 e a Corte Interamericana de Direitos Humanos. In: GOMES, Luiz Flávio; MAZZUOLI, Valerio de Oliveira. Crimes da ditadura militar. Uma análise à luz da jurisprudência atual da Corte Interamericana de Direitos Humanos. São Paulo: RT, 2011, p. 174-225. 
134 Cf. voto do Min. Cezar Peluso. Disponível em: <http://www.stf.jus.br/arquivo/cms/ noticiaNoticiaStfArquivo/ anexo/Ext1085CP.pdf>. Acesso em: 29 fev. 2012.

135 Cezar Peluso, Presidente do STF, 15/12/2010. O Estado de S. Paulo de 16/12/2010, p. A12; Folha de S. Paulo de $16 / 12 / 2010$, p. A 15.

136 “É uma decisão tomada no âmbito internacional e não no interno. O que nós decidimos no STF foi a partir do direito nacional. Na prática, o efeito será nenhum." (Marco Aurélio Mello, Ministro do STF, 15/12/2010. O Estado de S. Paulo de 16/12/2010, p. A12; Folha de S. Paulo de 16/12/2010, p. A15).

137 “Em termos internos, a decisão é completamente anódina. Poderá a OEA fazer algum tipo de advertência ao Brasil, mas ficará apenas na advertência diplomática. Não terá nenhum efeito.” (Nelson Jobim, Ministro da Defesa, 17/12/2010). Disponível em: <http://noticias.r7.com/brasil/noticias/ministro-da-justica-disse-que-condenacoesda-oea-sao-absolutamente-ineficazes-20101217.html>. Acesso em: 29 fev. 2012.

138 Disponível em: <http://www.estadao.com.br/estadaodehoje/20101216/not_imp654303,0.php>. Acesso em 28 jul. 2011. V. também: KRSTICEVIC, Viviana; AFFONSO, Beatriz. A Importância de se fazer justiça. Reflexões sobre os desafios para o cumprimento da obrigação de investigar e punir os responsáveis em observância à sentença da Corte Interamericana no caso da Guerrilha do Araguaia. In: GOMES, Luiz Flávio; MAZZUOLI, Valerio de Oliveira. Crimes da ditadura militar. Uma análise à luz da jurisprudência atual da Corte Interamericana de Direitos Humanos. São Paulo: RT, 2011, p. 251-274.

139 MAZZUOLI, Valerio de Oliveira. Curso de direito internacional público, cit., p. 896.

140 MAZZUOLI, Valerio de Oliveira. Curso de direito internacional público, cit., p. 896. Cf. ainda: MAGALHÃES, José Carlos de. O Supremo Tribunal Federal e o direito internacional: uma análise crítica. Porto Alegre: Livraria do Advogado, 2000, p. 102.

141 Há de concreto nesta questão apenas o Projeto de Lei n. 4.667/2004 em tramitação na Câmara Federal, que impõe à União a obrigatoriedade de pagar as indenizações às vítimas de violações de direitos humanos. MAZZUOLI, Valerio de Oliveira. Curso de direitos internacional público, cit., p. 900.

142 PIOVESAN, Flávia. Direitos humanos e o direito constitucional internacional, cit., p. 339-341.

143 GOMES, Luiz Flávio; MAZZUOLI, Valerio de Oliveira. Comentários à Convenção Americana sobre Direitos Humanos: Pacto de San José da Costa Rica, cit., p. 339-341; HOBSBAWM, Eric. A era dos extremos. $O$ breve século XX: 1914-1991. Tradução Marcos Santarrita. São Paulo: Companhia das Letras, 1995, p. 352; LAMBERT, Jean-Marie. Curso de direito internacional público: o Mercosul em questão. Goiânia: Kelps, 2002, v. IV, p. 158; e RAMOS, André de Carvalho. Processo internacional de direitos humanos: análise dos sistemas de apuração de violações dos direitos humanos e a implementação das decisões no Brasil. Rio de Janeiro: Renovar, 2002, p. 97-99.

144 TEIXEIRA, Gustavo de Faria Moreira. O greening no sistema interamericano de direitos humanos, cit., p. 219-227. Cf. também MINISTÉRIO DAS RELAÇÕES EXTERIORES. Nota n. 142. Solicitação da Comissão Interamericana de Direitos Humanos (CIDH) da OEA. 05/04/2011; e Declarações do diretor interino do Departamento de Direitos Humanos e Temas Sociais do Ministério das Relações Exteriores, Sílvio José Albuquerque e Silva à Agência Brasil em 04/05/2011. Disponível em: <http://agenciabrasil.ebc.com.br/noticia/2011-05-04/representante-doitamaraty-diz-que-brasil-nao-deslegitima-oea-por-medida-cautelar-sobre-belo-monte>. Acesso em: 09/03/2012.

\section{REFERÊNCIAS BIBLIOGRÁFICAS}

ALSTON, Philip. Conjuring up new human rights: a proposal for quality control. American Journal of International Law. vol. 78, p. 607-621, 1984. 
ANDERSON, Michael R.; BOYLE, Alan E. (Orgs.). Human rights approaches to environmental protection. Oxford: Oxford University Press, 1996.

ANKERSEN, Thomas T.; RUPPERT, Thomas K. Defending the polygon: the emerging human right to communal property. Oklahoma Law Review. v. 59, n. 4, p. 681-757, 2006.

AYALA CORAO, Carlos M. Recepción de la jurisprudencia internacional sobre derechos humanos por la jurisprudencia constitucional. Revista del Tribunal Constitucional, n. 6, Sucre, p. 9-63, nov. 2004.

BOBBIO, Norberto; MATTEUCCI, Nicola; e PASQUINO, Gianfranco. Dicionário de Política. Tradução Carmen Varriale et al. 5. ed. Brasília: Editora Universidade de Brasília: 2000.

BONAVIDES, Paulo. Curso de direito constitucional. 10. ed. São Paulo: Malheiros, 2000. . Do Estado liberal ao Estado social. 5. ed. Belo Horizonte: Del Rey, 1993.

BOYLE, Alan. Human rights and the environment: a reassessment. UNEP Human Rights and Environment. UNEP, 2010.

BUERGUENTHAL, Thomas. El derecho internacional de los derechos humanos en las Constituciones latinoamericanas y en la Corte Interamericana de Derechos Humanos. Revista Latinoamericana de Derecho. año 1, n. 1, p. 141-180, enero/junio 2004.

. International human rights. Minnesota: West Publishing, 1988.

CAMPOS, Bidart. Tratado de derecho constitucional argentino. Buenos Aires: Ediar, 1995, t. III.

CANÇADO TRINDADE, Antônio Augusto. A proteção internacional dos direitos humanos no limiar do novo século e as perspectivas brasileiras. Temas de política externa brasileira II. Brasília: Ministério das Relações Exteriores, 1994, v. I.

Desafios e conquistas do direito internacional dos direitos humanos no início do século XXI. In:

CACHAPUZ DE MEDEIROS, Antônio Paulo (Org.). Desafios do direito internacional contemporâneo. Brasília:

Fundação Alexandre Gusmão, p. 207-321, 2007.

Direito internacional e direito interno: suas interações na proteção dos direitos humanos.

Instrumentos internacionais de proteção dos direitos humanos. São Paulo: Centro de Estudos da Procuradoria Geral do Estado, p. 14-46, 1996.

Direitos humanos e meio ambiente: paralelo dos sistemas de proteção internacional. Porto Alegre: Sergio Antonio Fabris, 1993.

Os direitos humanos e o meio ambiente. In: SYMONIDES, Janusz (Org.). Direitos humanos: novas

dimensões e desafios. Brasília: Unesco Brasil, Secretaria Especial dos Direitos Humanos, p. 162-203, 2003.

Tratado de direito internacional dos direitos humanos. Porto Alegre: Sergio Fabris Editor, 1999, v. II.

Tratado de direito internacional dos direitos humanos. Porto Alegre: Sergio Fabris Editor, 2003, v. III.

El agotamiento de los recursos internos en el sistema interamericano de protección de los derechos humanos.

San José da Costa Rica/Brasília: Instituto Interamericano de Direitos Humanos, Comitê Internacional da Cruz Vermelha, Alto Comissariado das Nações Unidas para os Refugiados, Comissão da União Europeia, 1996.

CANOTILHO, Joaquim José Gomes. Direito constitucional ambiental português e da União Europeia. In:

CANOTILHO, Joaquim José; LEITE, José Rubens Morato (Orgs.). Direito constitucional ambiental brasileiro. 2.

ed. São Paulo: Saraiva, p. 1-11, 2008.

CASESSE, Antônio. Human rights in a changing world. Philadelphia: Temple University Press, 1990.

CHINKIN, Christine M. The challenge of soft law: development and change in international law. The

International and Comparative Law Quarterly, v. 38, n. 4, p. 850-866, oct./1989.

CHURCHILL, Robin. Environmental rights in existing human rights treaties. In: ANDERSON, Michael R.;

BOYLE, Alan E. (Orgs.). Human rights approaches to environmental protection. Oxford: Oxford University Press, p. 89-108, 1996.

CLAUDE, Richard Pierre; WESTON, Burns H. (Orgs.). Human rights in the world community: issues and action. Philadelphia: University of Pennsylvania Press, 1989

DONNELLY, Jack. Universal human rights in theory and practice. 2. ed. Ithaca, New York: Cornell University Press, 2003.

ENGLE, Eric. Third party effect of fundamental rights (Drittwirkung). Hanse Law Review, v. 5, n. 2, p. 165-173, 2009 FIX-ZAMUDIO, Hector. Protección jurídica de los derechos humanos. México: Comisión Nacional de Derechos Humanos, 1991.

FLORES, Joaquim Herrera. Direitos Humanos, interculturalidade e racionalidade de resistência, sequência. Revista do Curso de Pós-Graduação em Direito da UFSC, v. 23, n. 44, p. 9-30, 2002.

GARFIELD, Seth. A nationalist environment: indians, nature and the construction of the Xingu National Park in Brazil. Luso-Brazilian Review, v. 41, n. 1, p. 139-167, 2004.

GOMES, Carla Amado. Textos dispersos de direito do ambiente. Lisboa: Associação Acadêmica da Faculdade de Direito, 2010, v. III. 
GOMES, Luiz Flávio; MAZZUOLI, Valerio de Oliveira. Comentários à Convenção Americana sobre Direitos Humanos: Pacto de San José da Costa Rica. 3. ed. rev., atual e ampl. São Paulo: RT, 2010.

Crimes da ditadura militar. Uma análise à luz da jurisprudência atual da Corte

Interamericana de Direitos Humanos. São Paulo: RT, 2011.

GROSS ESPIELL, Héctor. Estudios sobre derechos humanos. Madrid: Civitas, 1988.

HENKIN, Louis. International law: politics, values and functions. Boston: Martinus Nijhoff, 1990. The age of rights. New York: Columbia University Press, 1990.

HOBSBAWM, Eric. A era dos extremos. O breve século XX: 1914-1991. Tradução Marcos Santarrita. São Paulo: Companhia das Letras, 1995.

JAYME. Erik. Identité culturelle et intégration: le droit international privé post-moderne. Recueil des Cours, v. 251, p. 9-267, 1995.

KISS, Alexandre. Os direitos e interesses das gerações futuras e o princípio da precaução. In: VARELLA, Marcelo Dias \& Platiau, Ana Flávia Barros (Orgs.). Princípio da Precaução. Belo Horizonte: Del Rey, 2004, p. 1-12.

; SHELTON, Dinah. Guide to international environmental law. Koninlijke Brill, NV, Leiden: Martinus Nijhoff Publishers, 2007.

. Judicial handbook on environmental Law. Nairobi: United Nations Environment

Programme, 2005. KNOX, John H. Linking human rights and climate change at the United Nations. Harvard Environmental Law Review. v. 33, Cambridge: Harvard Law School, p. 477-498, 2009.

KRSTICEVIC, Viviana; AFFONSO, Beatriz. A importância de se fazer justiça. Reflexões sobre os desafios para o cumprimento da obrigação de investigar e punir os responsáveis em observância à sentença da Corte Interamericana no caso da Guerrilha do Araguaia. In: GOMES, Luiz Flávio; MAZZUOLI, Valerio de Oliveira. Crimes da ditadura militar. Uma análise à luz da jurisprudência atual da Corte Interamericana de Direitos Humanos. São Paulo: RT, p. 251-274, 2011.

LAFER, Celso. A internacionalização dos direitos humanos: constituição, racismo e relações internacionais. Barueri: Manole, 2005. Ensaios sobre a liberdade. São Paulo: Perspectiva, 1980.

LAMBERT, Jean-Marie. Curso de direito internacional público: o Mercosul em questão. Goiânia: Kelps, 2002, v. IV. Curso de direito internacional público: o mundo global. 5. ed. Goiânia: Kelps, 2004.

LEDESMA, Hector Faúndez. El sistema interamericano de protección de los derechos humanos, aspectos institucionales y procesales. 3. ed. San José: IIDH, 2004.

LEITE, José Rubens Morato; AYALA, Patryck de Araújo. Dano ambiental: do individual ao coletivo extrapatrimonial. 3. ed. São Paulo: RT, 2010.

LINDGREN ALVES, José Augusto. O significado político da Conferência de Viena sobre direitos humanos. Revista dos Tribunais, n. 713, p. 284-288, março 1995.

O sistema internacional de proteção dos direitos e o Brasil. Arquivos do Ministério da Justiça. Brasília v. 46, n. 182, p. 85-114, jul./dez. 1993

MAGALHÃES, José Carlos de. O Supremo Tribunal Federal e o direito internacional: uma análise crítica. Porto Alegre: Livraria do Advogado, 2000.

MAGRAW, Daniel Barstow; BAKER, Lauren. Globalization and communities: community-based property rights and prior informed consent. Denver Journal of International Law and Policy. v. 35, n. 3 e 4, p. 413-428, 2008.

MANCHEGO, José F. Palomino; GARBONELL, José Carlos Remotti (Orgs.). Derechos humanos y constitución en Iberoamérica (Libro-homenaje a Germán J. Bidart Campos). Lima: Instituto Iberoamericano de Derecho Constitucional, 2002.

MAYZOLER, Marcel; ROUDART, Laurence. História das agriculturas no mundo: do neolítico à crise contemporânea. Tradução Cláudia F. Fallhuh Balduino Ferreira. São Paulo: Editora Unesp; Brasília: NEAD, 2010. MAZZUOLI, Valerio de Oliveira. Curso de direito internacional público. 5. ed. rev., atual. e ampl. São Paulo: RT, 2011. Direito dos tratados. São Paulo: RT, 2011.

. Direitos humanos e meio ambiente: um diálogo entre os sistemas internacionais de proteção. In:

MAZZUOLI, Valerio de Oliveira; IRIGARAY, Carlos Teodoro Hugueney (Orgs.). Novas perspectivas do direito ambiental brasileiro: visões interdisciplinares. Cuiabá: Cathedral, p. 61-92, 2009.

Direitos humanos, constituição e os tratados internacionais: estudo analítico da situação e aplicação do tratado na ordem jurídica brasileira. São Paulo: Editora Juarez de Oliveira, 2002.

Prisão civil por dívida e o Pacto de San José da Costa Rica. Rio de Janeiro: Forense, 2002.

Tratados internacionais de direitos humanos e o direito interno. São Paulo: Saraiva, 2010.

O controle jurisdicional da convencionalidade das leis. São Paulo: RT, 2009.

MELLO, Celso D. Albuquerque de. Curso de direito internacional público. 15. ed. rev. e atual. Rio de Janeiro: Renovar, 2004, v. II. 
MERON, Theodor (Org.). Human rights in international law: legal and policy issues. Oxford: Clarendon Press, 1984. MITCHELL, Ronald B. Problem structure, institutional design, and the relative effectiveness of international environmental agreements. Global Environmental Politics, v. 6, n. 3, p. 72-89, august, 2006.

OSOFSKY, Hari M. Inuit petition as a bridge? Beyond dialectics of climate change and indigenous people's rights. American Indian Law Review. v. 31, Norman: The University of Oklahoma College of Law, p. 675-698, 2007.

PIOVESAN, Flávia. Direitos humanos e o direito constitucional internacional. 7. ed. São Paulo: Saraiva, 2006. Direitos humanos: desafios e perspectivas contemporâneas. Revista do Instituto de Direito

Constitucional e Cidadania. Londrina, ano I, v. 1, p. 49-76, abr. 2005.

PLACENCIA, Luis González. Deconstructing human rights: a standpoint from the postmodern understanding of justice. Revista do Instituto Brasileiro de Direitos Humanos. Ano 3, v. 3, n. 3, p. 152-162, 2002.

RAMOS, André de Carvalho. Crimes da ditadura militar: a ADPF 153 e a Corte Interamericana de Direitos Humanos. In: GOMES, Luiz Flávio; MAZZUOLI, Valerio de Oliveira. Crimes da ditadura militar: uma análise à luz da jurisprudência atual da Corte Interamericana de Direitos Humanos. São Paulo: RT, p. 174-225, 2011. Direitos humanos em juízo: comentários aos casos contenciosos e consultivos da Corte Interamericana de Direitos Humanos. São Paulo: Max Limonad, 2001.

Processo internacional de direitos humanos: análise dos sistemas de apuração de violações dos direitos humanos e a implementação das decisões no Brasil. Rio de Janeiro: Renovar, 2002.

RAUBER, Jochen. The United Nations - a Kantian dream come true? Philosophical perspectives on the constitutional legitimacy of the World Organization. Hanse Law Review, The E-Journal on European, International and Comparative Law, v. 5, n. 1, p. 49-76, 2009.

SALDANHA, Nelson. O Estado moderno e a separação dos poderes. São Paulo: Saraiva, 1987.

SANDS, Philippe (Ed.). Greening international law. London: Earthscan Publications Limited, 1993. . Principles of international environmental law. Manchester: Manchester University Press, 1995.

SHELTON, Dinah. Environmental rights and Brazil's obligations in the Inter-American Human Rights System. George Washington International Law Review, v. 40, p. 733-777, 2008.

Human rights, environmental rights and the right to the environment. Stanford Journal of

International Law. v. 28, Palo Alto: Stanford University, p. 103-138, 1991.

Human rights, health and environmental protection: linkages in Law and practice. Health and

human rights working paper series, n. 1. Genebra: World Health Organization, p. 3-22, 2002.

SHIVA, Vandana. Biopirataria: a pilhagem do conhecimento. Tradução Laura Cardellini Barbosa de Oliveira. Petrópolis: Vozes, 2001.

SILVA, Geraldo Eulálio do Nascimento; ACCIOLY, Hildebrando. Manual de direito internacional público. 15. ed. São Paulo: Saraiva, 2002.

SILVA, José Afonso da. Direito ambiental constitucional. 3. ed. São Paulo: Malheiros, 2000.

SOARES, Guido Fernando Silva. A proteção internacional do meio ambiente. Barueri: Manole, 2003.

Dez anos após Rio-92: o cenário internacional, ao tempo da cúpula mundial sobre

desenvolvimento sustentável (Johanesburgo, 2002) In: MAZZUOLI, Valerio de Oliveira; IRIGARAY, Carlos Teodoro Hugueney (Orgs.). Novas perspectivas do direito ambiental brasileiro: visões interdisciplinares. Cuiabá: Cathedral, p. 11-65, 2009.

. Direito internacional do meio ambiente: emergências, obrigações e responsabilidades. São Paulo: Atlas: 2001.

SOHN, Louis B. The new international law: protection of the rights of the individuals rather than the states. American University Law Review, v. 32, n. 1, p. 1-64, 1982.

SOUSA SANTOS, Boaventura de. Uma concepção multicultural de direitos humanos. Revista Lua Nova, São Paulo, v. 39, p. 105-201, 1997.

SPILLER, Paula. The La Oroya case: the relationship between environmental degradation and human rights violation. Human rights brief. v. 18, issue 1, Washington D.C.: American University of Washington College of Law, p. 19-23, fall 2010.

STEINER, Henry. The youth of rights - review of Henkin: the age of rights. Harvard Law Review, v. 104, n. 4, p. 917-935, 1991.

; ALSTON, Philip. International human rights in context - law, politics and morals. 2. ed. Oxford: Oxford University Press, 2000.

STIGLITZ, Joseph E. Globalization and its discontents. New York-London: WW Norton Company, 2003. TEIXEIRA, Gustavo de Faria Moreira. O greening no sistema interamericano de direitos humanos. Curitiba: Juruá, 2011. VARVARIGOS, Dimitrios. Environmental degradation, longevity and the dynamics of economic development. Environmental and Resource Economics, v. 46, issue 1, p. 59-73, 2010.

VASAK, Karel. The international dimensions of human rights. Tradução e revisão Phillip Aston. Connecticut: Greenwood Press, 1982. 
VINCENT, R. J. Human rights and international relations. Cambridge: Cambridge University Press, 1986. WILSON, Sacoby M.; RICHARD, Roland; JOSEPH, Lesley; WILLIAMS, Edith. Climate change, environmental justice and vulnerability: an exploratory spatial analysis. Environmental Justice, v. 3, n. 1, p. 13 $19,2010$.

\section{Valerio de Oliveira Mazzuoli}

Faculdade de Direito da UFMT Av. Fernando Corrêa da Costa, n. 2.367 Bairro Boa Esperança - 78060-900 Cuiabá - MT - Brasil mazzuolidaufmt.br

Rua das Mangabas, n. 784 Cond. Alphaville, J. Itália -78061-320 Cuiabá - MT - Brasil gustavofmteixeiralahotmail.com
Pós-Doutor em CIÊnCIAS JuRÍdICO-Políticas PELA UNIVERSIDADE DE LISBOA Doutor summa Cum LaUde EM Direito InTERnacional PELA Universidade Federal do Rio Grande do SUl (UFRGS)

Mestre em DiReito PELA UNESP

Professor AdJunto nOS CURSOS dE GRAdUAÇ̄ão e de Mestrado em Direito da UFMT

\section{Gustavo de Faria Moreira Teixeira}

Mestre em Direito Agroambiental pela Universidade Federal de Mato Grosso (UFMT)

PROFESSOR DE DIREITO INTERNACIONAL NA UNIC

Advogado 
